\title{
PREDIKSI PERTUMBUHAN KELENJAR SUSU, PRODUKSI SUSU DAN INVOLUSI KELENJAR SUSU BERDASARKAN KONSENTRASI BEBERAPA HORMON DAN METABOLIT DALAM DARAH INDUK SELAMA KEBUNTINGAN PADA DOMBA EKOR TIPIS JAWA BARAT
}

\author{
Mas Yedi Sumaryadi ${ }^{1}$ dan Wasmen Manalu²
}

\section{INTISARI}

Profil hormon (progesteron, estradiol, triiodotironin, dan kortisol) dan metabolit darah (B-OH butirat [BHBA], dan nitrogen urea darah [BUN]) pada 45 ekor domba telah diukur setiap bulan selama kebuntingan. Delapan belas dan 27 ekor domba percobaan masing-masing dikorbankan pada awal dan akhir laktasi untuk menentukan komponen kimia kelenjar susu (berat kering bebas lemak kelenjar susu [DFFT], asam deoksiribonukleat [DNA], asam ribonukleat [RNA], dan kolagen). Selama laktasi domba diperah setiap bulan dan diberikan tambahan konsentrat 500 atau $1000 \mathrm{~g}$. Konsentrasi progesteron dan estradiol pada bulan ke-3 dan atau ke-4 kebuntingan dapat digunakan untuk memprediksi tingkat pertumbuhan dan perkembangan kelenjar susu pada awal laktasi dengan kisaran koefisien determinasi antara 66.9 dan $89.0 \%$. Sementara konsentrasi kortisol dan triidotironin dan metabolit darah tidak bisa digunakan sebagai penduga yang baik untuk pertumbuhan dan perkembangan kelenjar susu. Konsentrasi progesteron dan estradiol pada bulan ke-3 atau ke-4 kebuntingan dapat digunakan untuk memprediksi involusi kelenjar susu pada akhir laktasi, serta produksi susu pada bulan ke-1 laktasi dengan kisaran koefisien determinasi antara 66.9 dan $89.0 \%$. Penambahan konsentrat $100 \%$ dari $500 \mathrm{~g}$ menjadi $1000 \mathrm{~g} / \mathrm{ekor} / \mathrm{hari}$ sangat nyata untuk menahan laju involusi DFFT, DNA, RNA, dan kolagen kelenjar susu masing-masing $52.69,57.48,81.63$, dan $57.99 \%$, serta meningkatkan produksi susu
terutama pada induk beranak kembar sebesar $48.62 \%$. Metabolit. Kebuntingan, Laktasi, Domba)

Buletin Peternakan $23(2): 103-126,1999$

\footnotetext{
Laboratorium Fisiologi dan Reproduksi. Fakultas Peternakan. Universitas Jenderal Soedirman,
Purwokerto Purusan Fisiolc 16151 .
} 


\title{
PREDICTION OF MAMMARY GLAND GROWTH, MILK PRODUCTION AND MAMMARY INVOLUTION BASED ON THE CONCENTRATIONS OF SEVERAL HORMONES AND METABOLITES IN THE MATERNAL SERUM DURING PREGNANCY IN JAVANESE THIN-TAIL EWES
}

\begin{abstract}
The concentrations of several hormones (progesterone, estradiol, triiodothyronine, and cortisol) and metabolites ( $\mathrm{B}-\mathrm{OH}$ butyric acid [BHBA], and blood urea nitrogen [BUN]) in the serum of 45 ewes were measured monthly during pregnancy. Eighteen and 27 experimental ewes were sacrificed at parturition and at the end of lactation, respectively, for determination of mammary chemical indices (dry fat-free tissue [DFFT], DNA, RNA, and collagen). During lactation, half of the experimental ewes were given concentrate supplementation by $500 \mathrm{~g}$ and the others by $1000 \mathrm{~g} / \mathrm{d}$. Milk production was measured monthly. The concentrations of progesterone and estradiol at the third or/and on the fourth month of pregnancy could be used as good indicators to predict mammary gland growth and development at parturition, with coefficient of determination ranged from 66.9 to $89.0 \%$. The concentrations of triiodothyronine, cortisol, BHBA and BUN in the maternal cirsulation during pregnancy, however, could not be used to predict mammary growth and development at parturition. Maternal serum progesterone and estradiol at age 3 and 4 months of pregnancy could be used to predict mammary involution at the end of lactation and milk production for the first month of lactation with coefficients of determination ranged from 66.9 to $89.0 \%$. Concentrate supplementation by $1000 \mathrm{~g}$ daily significantly withheld mammary involution as indicated by DFFT, DNA, RNA, and collagen $52.69,57.48,81.63$, and $57.99 \%$, respectively, and increased milk production by $4862 \%$ in the ewes giving birth to multiple lambs.
\end{abstract}

(Key Words: Mammary Growth. Mammary Involution, Milk Production, Hormone, Metabolite, Pregnancy, Lactation, Sheep).

\section{Pendahuluan}

Total produksi susu selama laktasi dipengaruhi oleh tingkat perkembangan kelenjar susu yang dicapai pada awal laktasi (Sheffield dan Anderson, 1985; Anderson, 1985; Tucker, 1987), laju penyediaan zat-zat makanan ke kelenjar susu dan kelengkapan perangkat sintesis dan aktivitas sel-sel kelenjar susu (enzim-enzim dan hormon) selama laktasi, serta laju involusi (Djojosoebagio. 1965: Sheffield dan Anderson, 1985 Anderson. 1985: Wilde dan Knight, 1989). Aktivitas sel-sel kelenjar susu akan meningkat jika hormon-hormon dan enzim yang terlibat dalam sintesis air susu cukup tersedia secara optimal.

Pertumbuhan dan perkembangan kelen- jar susu sampai fungsional mensintesis susu terjadi selama kebuntingan yang dipengaruhi oleh kelompok hormon mammogenik yaitu kelompok hormon yang merangsang tumbuhkembang kelenjar susu (Knight dan Peaker, 1982; Anderson, 1985; Imagawa ef al, 1985; Winder dan Forsyth, 1986; Imagawa et al, 1986, Tucker, 1987). Pada ternak ruminansia kecil seperti kambing dan domba, pertumbuhan dan perkembangan kelenjar susu meningkat secara pesat selama paruh kedua kebuntingan (Rattray el al., 1974; Anderson, 1975; Anderson et al., 1981) bersama-sama dengan peningkatan konsentrasi hormon-hormon mammogenik dalam serum induk.

Pada saat kebuntingan, hormon reproduksi seperti progesteron, estrogen, dan laktogen plasenta akan meningkat yang selain 
berfungsi untuk mendukung pertumbuhan embrio, uterus dan plasenta, juga berfungsi untuk mempersiapkan kelenjar susu untuk mensintesis air susu setelah melahirkan.

Pertumbuhan dan perkembangan kelenjar susu sudah dibuktikan mempunyai korelasi yang positif dengan produksi susu (Sheffield dan Anderson, 1985). Hormon lain yang masih perlu dikaji adalah tiroksin, kortisol, prolaktin, dan somatotropin, walaupun konsentrasi hormon-hormon ini tidak berubah drastis selama periode kebuntingan. Potensi hormon-hormon tersebut dalam mamogenesis sudah banyak dibuktikan melalui penambahan secara eksogen pada tikus (Djojosoebagio, 1965) dan dikombinasikan dengan progesteron, estradiol, relaksin dan laktogen plasenta pada hewan ovariektomi (Harness dan Anderson, 1977a,b; Wright dan Anderson, 1982; Forsyth, 1986; Wahab dan Anderson, 1989). Namun penubahan hormon tersebut sesuai dengan usia kebuntingan dan perkembangan kelenjar susu masih perlu diteliti pada domba lokal di Indonesia.

Domba ekor tipis sudah terkenal akan prolifikasinya yang tinggi. Dengan semakin banyaknya anak yang dikandung oleh induk yang bunting, estrogen dan progesteron yang beredar dalam darah induk akan semakin tinggi. Telah diketahui bahwa peningkatan jumlah anak sangat erat kaitannya dengan laju ovulasi (Piper dan Bindon, 1984; Bradford, 1985; Bradford et al., 1986). Dengan meningkatnya jumlah ovulasi maka jumlah korpus luteum pensekresi hormon progesteron dan estradiol juga akan meningkat (Sumaryadi dan Manalu, 1995a). Dengan meningkatnya jumlah anak maka massa jaringan plasenta juga akan meningkat (Hayden e't al., 1979; Manalu et al, 1998).

Selama periode laktasi, pertumbuhan dan perkembangan kelenjar susu boleh dikatakan sudah berhenti. karena konsentrasi hormon-hormon yang merangsang perkembangan kelenjar susu, terutama progesteron, estradiol, dan laktogen plasenta sudah menurun atau sangat rendah (Anderson $c t a l$. 1981; Forsyth. 1986). Pada saat ini kecukupan aliran substrat ke kelenjar susu dan laju kematian sel-sel sekretoris mempunyai peranan yang dominan dalam sintesis komponen air susu per sel sekretoris kelenjar susu (Collier, 1985). Dengan demikian, tingkat produksi susu selama laktasi akan dipengaruhi oleh penyediaan substrat (zat-zat makanan) untuk sintesis komponen air susu (Davis dan Collier, 1983; Collier, 1985, Coppock, 1985), dan jumlah sel-sel sekretoris yang aktif (Djojosebagio, 1965; Anderson, 1985; Wilde dan Knight, 1989; Forsyth, 1996). Kekurangan aliran substrat ke kelenjar susu dan kematian sel-sel sekretoris (laju involusi) yang lebih cepat pada saat laktasi merupakan penyebab penurunan produksi. Hal ini mengingat produksi susu merupakan fungsi jumlah sel-sel sekretoris yang aktif dan aktivitas metabolik kelenjar susu (Davis dan Collier, 1983). Namun apakah laju involusi sel-sel sekretoris kelenjar susu dapat diperlambat? Diduga, dengan meningkatkan aliran substrat, sel-sel sekrestoris akan lebih aktif sehingga akan lebih lambat mati.

\section{Bahan dan Metode}

\section{Pemeliharaan domba percobaan}

Hewan percobaan yang digunakan dalam penelitian ini adalah 45 ekor domba ekor tipis (masing-masing 20, dan 19 ekor yang mengandung anak 1, dan 2-3, dan 6 ekor yang tidak bunting sebagai kontrol) dengan rataan bobot badan awal sebelum perkawinan $20.47 \pm 1.23 \mathrm{~kg}$ dengan koefisien keragaman 805 persen. Sebelum perkawinan, domba percobaan diadaptasikan selama satu bulan dengan lingkungan percobaan, dan dicukur bulunya untuk mengurangi cekaman panas. Setiap domba percobaan ditempatkan dalam kandang individu yang berbentuk panggung dengan ukuran $1.0 \times 0.60 \mathrm{~m}$ dan dilengkapi dengan tempat makan maupun air minum. Selama kebuntingan, pakan yang diberikan berupa ransum basal rumput raja kering secara al lihitum, dan makanan tambahan berupa konsentrat $500 \mathrm{~g} / \mathrm{ekor} / \mathrm{hari}$. Mineral diberikan pada setiap domba sebanyak $0.1 \mathrm{~g} / \mathrm{kg}$ bobot 
badan, sedangkan air minum tersedia secara ad libitum sepanjang hari

\section{Rancangan percobaan}

Konsentrasi hormon dan metabolit darah domba percobaan diukur setiap bulan sejak mulai masa kebuntingan sampai melahirkan. Sebelumnya, siklus berahi domba diseragamkan dengan penyuntikan $\mathrm{l} \mathrm{ml}$ prostaglandin ( $\mathrm{PGF}_{2 u}$, Prosolvin, Intervet, North Holland) yang diulang setelah 11 hari, kemudian dicampur dengan pejantan (rasio 1.5) selama dua periode berahi. Sampel darah diambil dari induk domba sebulan sekali (pada waktu yang sama) selama periode kebuntingan untuk analisis progesteron, estradiol, triiodotironin, kortisol dengan metode RIA, serta $\mathrm{B}-\mathrm{OH}$ butirat (BHBA), dan nitrogen urea darah (BUN) dengan metode spektrofotometer. Pada saat kelahiran. 15 induk yang bunting dan 3 ekor kontrol dikorbankan, kemudian kelenjar susu dipisahkan untuk mengetahui bahan kering bebas lemak kelenjar susu (DFFT), asam deoksiribonukleat (DNA), asam ribonukleat (RNA), dan kolagen yang masingmasing sebagai indikator total massa, populasi sel, aktivitas sintesis, dan jaringan ikat kelenjar susu. Hubungan antara konsentrasi hormon serta metebolit darah induk dan komponen kimia kelenjar susu ditelaah dengan analisis regresi ganda.

Pada saat laktasi, 24 ekor domba sisanya dikelompokkan berdasarkan tingkat pemberian konsentrat (500 dan $1000 \mathrm{~g} /$ ekor/ hari) dan jumlah anak yang dilahirkan (masing-masing terdiri atas induk yang heranak tunggal [ 11 ekor] dan kembar 2 sampai 3 [13 ekor]). Produksi susu setiap induk domba diukur sebulan sekali (4 minggu) sejak bulan ke-1 periode laktasi. Pada akhir laktasi, induk domba tersebut dikorbankan, kemudian kelenjar susu dipisahkan untuk digunakan dalam penentuan bahan kering bebas lemak (DFFT), asam deoksiribonukleat (DNA), asam ribonukleat (RNA), dan kolagen sebagai indikator involusi kelenjar susu akhir laktasi. Sebagai pembanding dalam percobaan ini digunakan 3 ekor induk domba yang tidak bunting dan tidak laktasi (kosong). Data profil hormon dan metabolit darah induk selama periode kebuntingan digunakan sebagai dasar untuk memprediksi involusi kelenjar susu akhir laktasi dan produksi susu dengan analisis regresi ganda.

\section{Sampling darah}

Sepuluh mililiter sampel darah domba diambil dari vena jugularis dengan menggunakan tabung injeksi steril atau vacutainer sebulan sekali pada pagi hari dan waktu yang sama selama periode kebuntingan dan laktasi. Sampel darah didinginkan $5^{\circ} \mathrm{C}$ selama dua jam, kemudian disentrifuge dengan kecepatan $2500 \mathrm{rpm}$ selama 30 menit untuk memisahkan serum dari gumpalan sel-sel darah. Sampel serum ini disimpan pada suhu $-20^{\circ} \mathrm{C}$ sampai digunakan dalam pengukuran kadar hormon dan metabolit darah.

\section{Analisis hormon dan metabolit darah}

Progesteron. Konsentrasi progesteron dalam serum diukur dengan radioimmunoassai teknik fase padat dengan menggunakan kit (Diagnostic Products Corporation [DPC], Los Angeles, CA). Sampel serum darah yang dipakai untuk analisis progesteron pada awal kebuntingan adalah $100 \mu$ l, kemudian setelah minggu ke-13 periode kebuntingan, volume sampel diperkecil menjadi $50 \quad \mu 1$ untuk memasukkan konsentrasi progesteron sampel ke kisaran standar yang digunakan. Kisaran standar yang digunakan untuk membuat kurva standar adalah mulai dari 0,1 sampai $20 \mathrm{ng} / \mathrm{ml}$. Semua kadar progesteron sampel berada dalam kisaran standar yang digunakan, dengan koefisien variasi intraassai 6 persen dan interassai di bawah 5 persen. Hasil pengukuran dengan volume sampel $50 \mu \mathrm{l}$ paralel dengan hasil pengukuran volume sampel 100 $\mu \mathrm{l}$. Dengan demikian, pengenceran sampel serum tidak mempengaruhi konsentrasi akhir yang akan diukur.

Estradiol. Konsentrasi estradiol dalam serum diukur dengan radioimmunoassai teknik fase padat dengan menggunakan kit (Diagnostic Products Corporation [DPC], Los Angeles, 
CA). Sampel serum darah yang dipakai untuk analisis estradiol pada awal kebuntingan adalah $300 \mu \mathrm{l}$, kemudian setelah minggu ke-16 periode kebuntingan, volume sampel diperkecil menjadi $100 \mu \mathrm{l}$ agar konsentrasi estradiol sampel ada pada kisaran standar yang digunakan yaitu antara 20 sampai 150 $\mathrm{ng} / \mathrm{ml}$. Semua kadar estradiol sampel berada dalam kisaran standar yang digunakan, dengan koefisien variasi intraassai 7 persen dan interassai di bawah 6 persen. Hasil pengukuran dengan volume sampel $300 \mu \mathrm{l}$ paralel dengan hasil pengukuran volume sampel 100 ul. Dengan demikian, pemekatan sampel serum tidak mempengaruhi konsentrasi akhir yang akan diukur.

Kortisol. Konsentrasi kortisol dalam senum diukur dengan radioimmunoassai teknik fase padat dengan menggunakan kit (DPC, Los Angeles, CA) Sampel serum darah yang dipakai untuk analisis kortisol adalah $50 \mu \mathrm{I}$, dipekatkan dua kali dari $25 \mu \mathrm{l}$ yang direkomendasikan oleh pabrik pembuat kit, mengingat kadar kortisol ruminansia lebih rendah dibandingkan dengan hewan monogastrik. Kisaran standar yang digunakan untuk membuat kurva standar adalah mulai dari I sampai $20 \mu \mathrm{g} / \mathrm{dl}$ Semua kadar kortisol sampel berada dalam kisaran standar yang digunakan, dengan koefisien variasi intraassai 3 persen Hasil pengukuran paralel pada ukuran sampel 25,50 , dan $100 \mu \mathrm{l}$

Triiodotironin (T3). Konsentrasi triiodotironin dalam serum diukur dengan radioimmunoassai teknik fase padat dengan menggunakan kit (DPC, Los Angeles, CA) Sampel serum darah yang dipakai untuk analisis triiodotironin adalah $100 \mu \mathrm{l}$. Kisaran standar yang digunakan untuk membuat kurva standar adalah mulai dari 20 sampai $200 \mathrm{ng} / \mathrm{ml}$. Semua kadar triiodotironin sampel berada dalam kisaran standar yang digunakan, dengan koefisien variasi intraassai 4 persen Hasil pengukuran paralel pada ukuran sampel 75 . 100, dan $150 \mu 1$

Nitrogen urea darah (BUN). Konsentrasi BUN diukur dengan menggunakan teknik enzimatik memakai kit (Sigma Chemical Co.,
St Louis, MO) yang sudah tersedia dengan kisaran standar 15 sampai $75 \mathrm{mg} / \mathrm{dl}$ Semua kadar BUN sampel berada dalam kisaran standar yang digunakan, dengan koefisien variasi intraassai 2 persen.

$\beta-O H$ butirat. Konsentrasi $\mathrm{B}-\mathrm{OH}$ butirat (BHBA) diukur dengan menggunakan teknik enzimatik melalui kit (Sigma chemical Co., St Louis, MO) yang tersedia dengan kisaran standar 5 sampai $50 \mathrm{mg} / \mathrm{dl}$ Semua kisaran B-OH sampel berada dalam kisaran standar yang digunakan, dengan koefisien variasi intraassai 2 persen.

\section{Komponen kimia kelenjar susu}

Pada akhir kebuntingan (saat kelahiran) induk domba dikorbankan, dan kelenjar susu dipisahkan. Sebelah dari kelenjar susu yang telah terpisah dibersihkan dari kulit, puting, jaringan lemak dan kemudian sedapat mungkin air susu dikeluarkan. Jaringan kelenjar susu dibekukan dan kemudian diiris tipis-tipis sebelum direndam dalam etanol selama 48 jam dan dalam eter selama $2 \times 24$ jam untuk menghilangkan lemak. Jaringan yang telah bebas lemak dikeringkan dalam oven pada suhu $52^{\circ} \mathrm{C}$ selama 48 jam, dan kemudian ditimbang untuk mendapatkan bobot kering bebas lemak (DFFT) yang mengandung jaringan parenkima dan stroma yang bukan lemak. Selanjutnya jaringan tersebut dibuat serbuk halus yang akan digunakan untuk analisis kadar DNA dengan metode reaksi nitrofenilhidrazin (Webb dan Levy, 1955), RNA dengan reaksi orsinol (Albaum dan Umbreit, 1947), kolagen dengan mengukur hidroksiprolin (Woessner, 196I).

\section{Analisis statistik}

Prediksi pertumbuhan kelenjar susu awal laktasi berdasarkan profil hormon dan metabolit darah selama kebuntingan dituangkan dalam suatu persamaan regresi, sebagai
berikut: di mana.

$$
\mathrm{Yi}=\text { aio }+\Sigma \text { bij } \mathrm{Hij}+\Sigma \text { cij } \mathrm{Mij}+\mathrm{K}
$$

$\mathrm{Yi}=$ karakteristik tentang komponen kimia kelenjar susu pada awal laktasi, pada 
akhir laktasi dan produksi susu selama laktasi dari induk yang melahirkan $\mathrm{i}$ ekor anak $(\mathrm{i}=1$, 2-3).

aio konstanta (intersep).

bij $=$ koefisien regresi profil hormon pada bulan ke-j $(j=1,2,3,4)$ dari induk yang melahirkan $i$ ekor anak $(\mathrm{i}=1,2-3)$

cij $=$ koefisien regresi metabolit darah pada bulan ke-j $(j=1,2,3,4)$ dari induk yang melahirkan $\mathrm{i}$ ekor anak $(i=1,2-3)$.

Hij = profil hormon pada bulan ke-j $(j=$ $1,2,3,4)$ dari induk yang melahirkan $i$ ekor anak $(i=1,2-3)$.

Mij = profil metabolit darah pada bulan $k e-j(j=1,2,3,4)$ dari induk yang melahirkan $i$ ekor anak $(i=1,2-3)$.

Untuk analisis awal laktasi, $K=0$, untuk induk yang beranak tunggal, 1, untuk induk yang beranak kembar 2 sampai 3 ekor. Untuk analisis selama laktasi dan akhir laktasi. $\mathrm{K}=0$, untuk induk yang diberi $500 \mathrm{~g}$ konsentrat/hari dan 1, untuk induk yang diberi $1000 \mathrm{~g}$ konsentrat/hari.

\section{Hasil dan Pembahasan}

Rataan konsentrasi progesteron, estradiol, triiodotironin (T3), kortisol, serta asam B-hidroksi butirat (BHBA) dan nitrogen urea darah (BUN) selama periode kebuntingan berdasarkan banyaknya anak yang dilahirkan disajikan pada Tabel 1. Data pada Tabel I menunjukkan bahwa rataan konsentrasi hormon dan metabolit darah induk selama kebuntingan meningkat berdasarkan banyaknya anak yang dilahirkan. Peningkatan progesteron, estradiol, triiodotironin, kortisol, $\mathrm{B}-\mathrm{OH}$ butirat, dan BUN pada induk yang melahirkan anak kembar 2 sampai 3 masing-masing sebesar $47.14,22.91,2.54$, $17.11,17.37$, dan $5.43 \%$ jika dibandingkan dengan induk yang melahirkan anak tunggal. Namun kisaran progesteron dan estradiol (Jarrell dan Dziuk, 1991; Gemmell, 1995; Manalu ef al., 1996; Manalu dan Sumaryadi, 1998a,b), triiodotironin dan kortisol (Lindner. 1964; Paterson dan Harrison, 1967; Manalu ef al, 1997; Manalu dan Sumaryadi, 1996). B-OH butirat dan BUN (Foot ef al., 1984; Annison el al., 1984; Manalu dan Sumaryadi, $1998 \mathrm{c})$ masih sesuai dengan kisaran yang dilaporkan pada kambing maupun domba

Table 1. Rataan konsentrasi progesteron, estradiol, triiodotironin, kortisol, beta-hidroksi asam butirat dan nitrogen urea darah induk selama periode kebuntingan pada domba yang tidak bunting (kosong), domba yang mengandung anak tunggal, dan anak kembar

\begin{tabular}{|c|c|c|c|}
\hline \multirow{4}{*}{$\begin{array}{l}\text { Progesteron, } \mathrm{ng} / \mathrm{ml} \\
\text { Estradiol, } \mathrm{pg} / \mathrm{ml}\end{array}$} & \multicolumn{3}{|c|}{ Jumlah anak (ekor) } \\
\hline & Kosong $(0)$ & Tunggal (1) & Kembar $(2-3)$ \\
\hline & $2.82 \pm 0.46^{\circ}$ & $13.45 \pm 0.70^{\mathrm{b}}$ & $19.79 \pm 0.95^{\circ}$ \\
\hline & $2.61 \pm 0.12^{\mathrm{a}}$ & $13.53 \pm 0.95^{b}$ & $16.63 \pm 1.05^{\circ}$ \\
\hline Triiodotironin, ng/m! & $90.21 \pm 6.94^{a}$ & $\pm 3.08^{a}$ & $96.76 \pm 3.67^{a}$ \\
\hline Kortisol, ng/ml & $8.70 \pm 0.67^{n}$ & $\pm 0.59^{\mathrm{b}}$ & $12.66 \pm 0.73^{b}$ \\
\hline BHBA, mg/dl' & $9.56 \pm 0.56^{\mathrm{a}}$ & $\pm 0.41^{\prime \prime}$ & $14.66 \pm 0.64^{\circ}$ \\
\hline $\mathrm{BUN}, \mathrm{mg} / \mathrm{dl}^{2}$ & $23.38 \pm 1.13^{\mathrm{a}}$ & $+0.95^{3}$ & $25.84 \pm 0.76^{a}$ \\
\hline
\end{tabular}

'BHBA adalah beta-hidroksi asam butirat ( $\beta-\mathrm{OH}$ butirat).

${ }^{2} \mathrm{BUN}$ adalah nitrogen urea dalam darah 
Tabel 2. Rataan DFFT, DNA, RNA, dan kolagen kelenjar susu pada awal laktasi berdasarkan jumlah anak yang dilahirkan

\begin{tabular}{|c|c|c|c|}
\hline \multirow{3}{*}{$\begin{array}{l}\text { Komponen kimia } \\
\text { kelenjar susu } \\
\text { DFFT, g }\end{array}$} & \multicolumn{3}{|c|}{ Jumlah anak yang dilahirkan (ekor) } \\
\hline & Kosong $(0)$ & Tunggal (1) & Kembar (2 - 3) \\
\hline & $2.63 \pm 0.12^{6}$ & $26.40 \pm 2.02^{6}$ & $45.88 \pm 10.56^{\mathrm{n}}$ \\
\hline DNA, mg & $103.56 \pm 12.58^{\circ}$ & $916.50 \pm 87.42^{b}$ & $1511.30 \pm 299.41^{\mathrm{A}}$ \\
\hline RNA, mg & $28.37 \pm 1.87^{\circ}$ & $297.24 \pm 46.17^{\mathrm{h}}$ & $937.44 \pm 229.00^{2}$ \\
\hline Kolagen, mg & $108.54 \pm 1.41^{b}$ & $346.98 \pm 40.46^{\mathrm{a}}$ & $354.37 \pm 43.38^{*}$ \\
\hline
\end{tabular}

Profil hormon dan metabolit darah induk domba selama kebuntingan ternyata meningkat dengan bertambahnya umur kebuntingan (Gambar 1), terutama pada bulan ke-3 kebuntingan. Keadaan ini diduga ada tujuan lain selain mempertahankan kebuntingan itu sendiri, terutama terhadap pertumbuhan kelenjar susu yang pesat pada saat ini. Ini berarti bahwa ada indikasi hubungan antara konsentrasi hormon dan metabolit darah dengan pertumbuhan dan perkembangan kelenjar susu selama kebuntingan.

Keterangan tentang profil hormon dan metabolit darah pada bulan ke-1 kebuntingan belum dapat dipakai untuk memprediksi pertumbuhan kelenjar susu awal laktasi ( $P>0.05)$. Karena itu usaha memprediksi pertumbuhan kelenjar susu dilakukan dengan menggunakan keterangan tentang profil hormon dan metabolit darah bulanan, masingmasing pada bulan ke-2, ke-3, dan ke-4 kebuntingan.

Komponen kimia kelenjar susu diukur melalui indikator bahan kering bebas lemak (DFFT), DNA, RNA, dan kolagen. Rataan indikator kimia pertumbuhan kelenjar susu pada awal laktasi berdasarkan banyaknya anak yang dilahirkan atau disusui disajikan pada Tabel 2. Tabel 2 menunjukkan bahwa kisaran nilai indikator komponen kimia kelenjar susu yang ditemukan dalam penelitian ini jauh lebih kecil dibandingkan dengan yang diamati pada domba (Rattray et al., 1974; Anderson, 1975) maupun pada kambing (Anderson et al.,
1981). Rendahnya pertumbuhan dan perkembangan kelenjar susu domba lokal Indonesia diduga akibat konsentrasi hormon yang merangsang pertumbuhan kelenjar susu belum optimal. Faktor lingkungan maupun genetik bisa mempengaruhi sekresi hormon. Jika satu atau beberapa hormon yang mempengaruhi pertumbuhan kelenjar susu disekresikan dalam jumlah terbatas, maka ukuran kelenjar susu juga akan terbatas (Turner, 1959).

Secara umum nilai rataan seluruh indikator komponen kimia kelenjar susu (Tabel. 2) meningkat berdasarkan banyaknya anak yang dilahirkan. Hal ini tidak terlepas dari peranan hormon, terutama progesteron dan estradiol yang sekresinya meningkat pesat pada induk yang melahirkan anak kembar (Gambar 1) dalam perangsangan pertumbuhan kelenjar susu. Prediksi DFFT, DNA, RNA dan kọlagen kelenjar susu pada awal laktasi dengan analisis regresi ganda berdasarkan keterangan profil hormon dan metabolit darah selama kebuntingan menghasilkan koefisien determinasi dan standar eror seperti disajikan pada Tabel 3. Pada tabel tersebut terlihat bahwa triiodotironin, kortisol, BHBA dan BUN mempunyai korelasi yang sangat kecil dengan indeks pertumbuhan dan perkembangan kelenjar susu, walaupun sepintas kelihatan (Gambar 1) bahwa irama kenaikan hormon dan metabolit tersebut mirip dengan progesteron dan estradiol. Dengan demikian, konsentrasi triiodotironin, kortisol, BHBA dan BUN dalam serum induk selama kebuntingan 

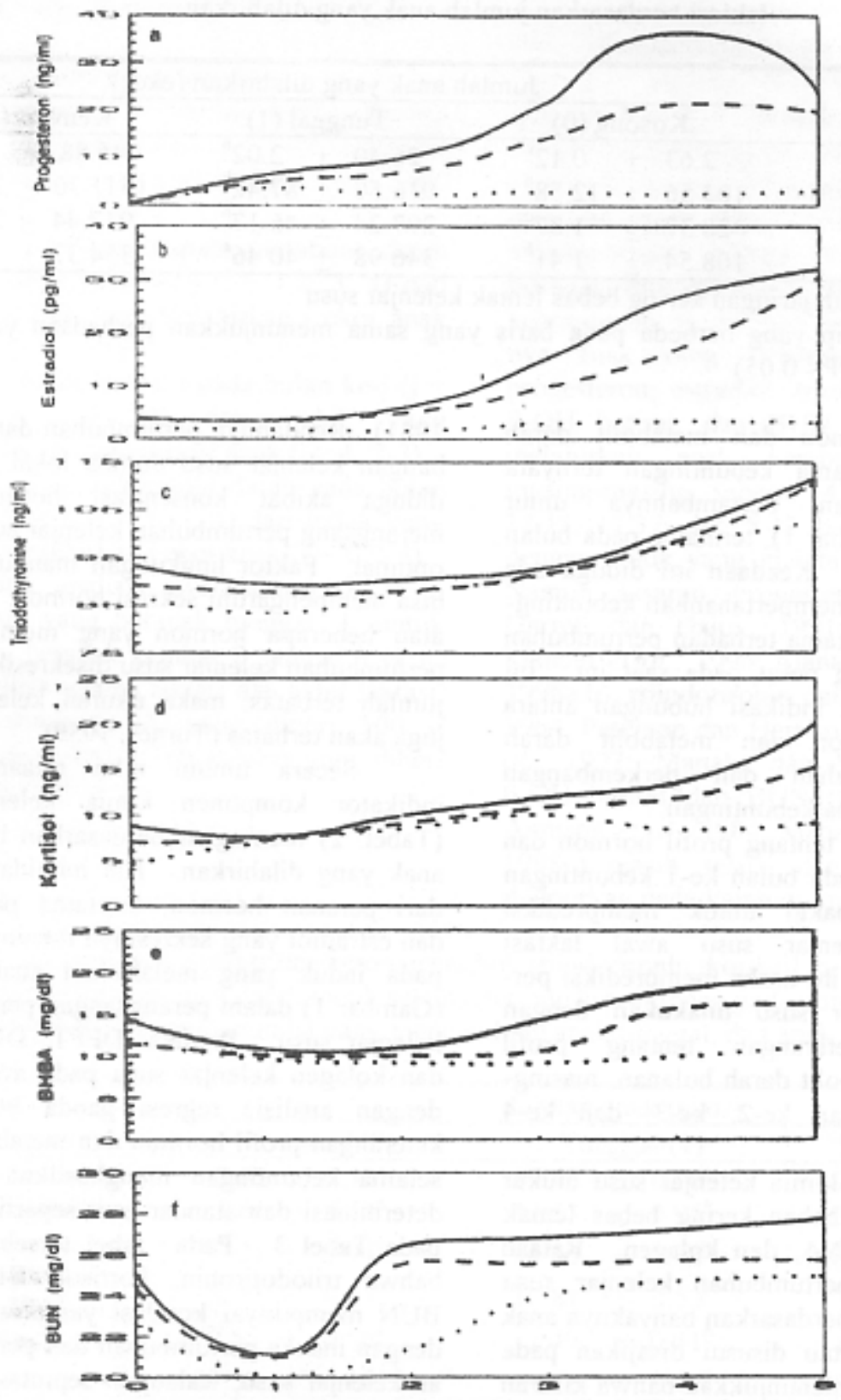

Periode setelah kawin (bulan)

Gambar 1. Profil progesteron (a), estradiol (b), triiodotironin (c), kortisol (d), beta-hydroksi butirat (BHBA) (e), dan nitrogen urea darah (BUN) (f) dari 0 sampai 5 bulan setelah perkatvinan pada domba yang tidak bunting (•ee), domba yang mengandung anak tunggal (---) dan anak kembar 2-3 (-). 
tidak dapat digunakan sebagi penduga pertumbuhan dan perkembangan kelenjar susu pada awal laktasi.

Tabel 3. menunjukkan bahwa penggunaan keterangan konsentrasi progesteron dan estradiol sampai bulan ke-2 untuk memprediksi DFFT, DNA, RNA, dan kolagen kelenjar susu belum memberikan pengaruh yang nyata $(\mathrm{P}>0.05)$, dengan koefisien determinasi yang masih rendah (16.8-33.2\%) dan kisaran standar eror yang relatif tinggi (30.7-62.2\%). Persentase koefisien determinasi untuk DFFT, DNA, RNA, dan kolagen masing-masing akan meningkat menjadi $92.3,88.0,88.6$ dan $57.7 \%$ dengan standar eror $15.5,19.8,28.1$, dan $32.8 \%$ jika keterangan tentang konsentrasi progesteron dan estradiol pada bulan ke- 3 juga digunakan. Peningkatan persentase koefisien determinasi sangat nyata $(\mathrm{P}<0.01)$ untuk DFFT $(75.5 \%)$, DNA $(55.0 \%)$, RNA $(56.5 \%)$, dan kolagen $(14.6 \%)$, dibandingkan dengan jika hanya menggunakan progesteron dan estradiol pada bulan ke-2 kebuntingan. Ini berarti bahwa persentase koefisien determinasi meningkat dengan diketahui tambahan keterangan konsentrasi progesteron dan estradiol pada bulan ke-3. Bahkan penggunaan keterangan konsentrasi progesteron dan estradiol pada bulan ke-3 saja sangat nyata $(P<0.01)$ untuk memprediksi DFFT, DNA, dan RNA kelenjar susu masing-masing dengan koefisien determinasi $89.0,86.3$, dan $83.9 \%$ serta standar eror 16.8, 19.5, dan $30.3 \%$ Namun untuk memprediksi kolagen kelenjar susu selain keterangan konsentrasi progesteron dan estradiol pada bulan ke-3 masih diperlukan tambahan keterangan konsentrasi kedua hormon tersebut pada bulan ke-4 sehinga diperoleh koefisien determinasi $68.3 \%$ dan standar eror $23.4 \%$. Koefisien determinasi akan meningkat jika hanya digunakan keterangan konsentrasi progesteron dan estradiol pada bulan ke-4 masing-masing untuk DFFT, DNA, RNA, dan kolagen adalah $89.3,87.3,85.9$, dan $50.7 \%$ dengan standar eror $18.3,21.5,30.9$, dan $23.4 \%$. Namun persentase peningkatan koefisien determinasi untuk DFFT, DNA, RNA, dan kolagen masing-masing $0.3,1.0,2.0$, dan $4.2 \%$

Tabel 3. Koefisien determinasi $\left(\mathbf{R}^{2}\right)$ dan standar error (SE) dari rataan DFFT, DNA, RNA, dan kolagen kelenjar susu pada awal laktasi berdasarkan konsentrasi hormon dan metabolit dalam darah induk domba

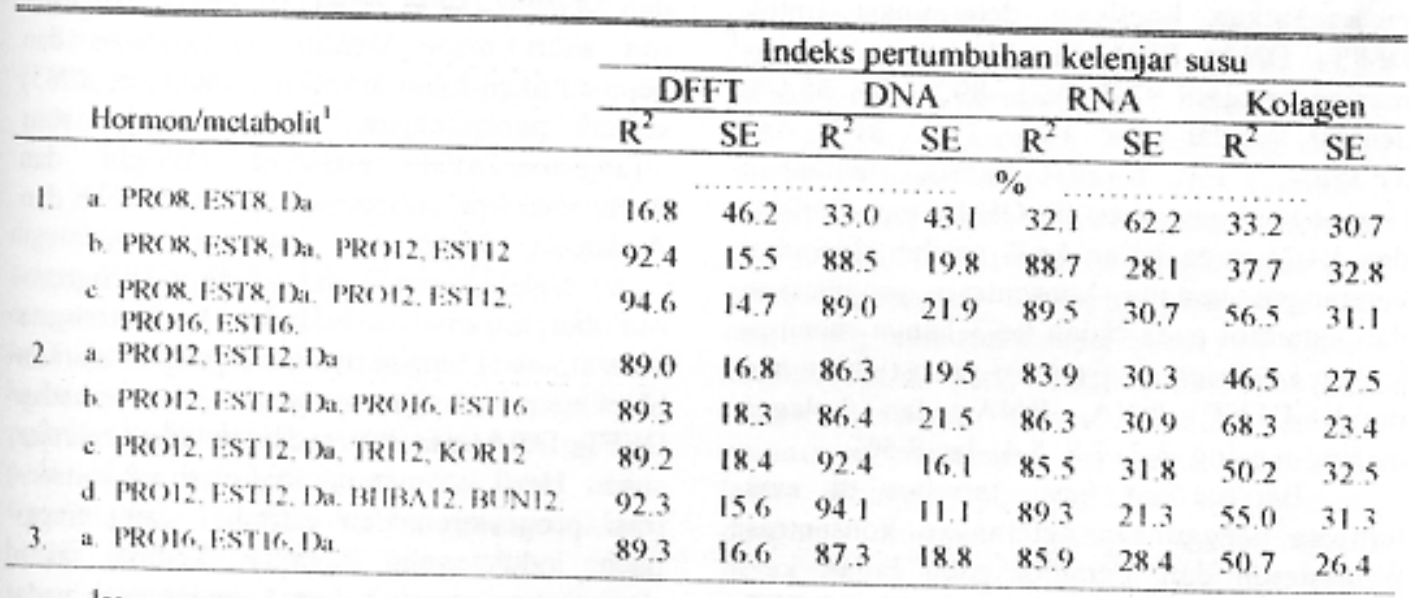

'Konsentrasi PRO = Progesteron; EST $=$ Estradiol; TRI $=$ Triiodotironin, $K O R=$ Kortisol, $\mathrm{BHBA}=\beta-\mathrm{OH}$ butirat; dan BUN $=$ Nitrogen urea darah. Angka setelah singkatan adalah umur kebuntingan dalam minggu. Da adalah dummy untuk jumlah anak. 
dibandingkan dengan jika hanya menggunakan keterangan tentang konsentrasi progesteron dan estradiol bulan ke-3

Demikian pula keterangan progesteron dan estradiol bulan ke-4 menghasilkan persentase standar eror dari DFFT, DNA, RNA dan kolagen yang relatif sama dibandingkan dengan jika hanya menggunakan keterangan tentang konsentrasi progesteron dan estradiol bulan ke-3

Prediksi berdasarkan keterangan konsentrasi progesteron, estradiol, triiodotironin, dan kortisol pada bulan ke-3 terhadap DFFT, DNA, RNA, dan kolagen kelenjar susu awal laktasi masing-masing menghasilkan koefisien determinasi $89.2,92.4,85.5$ dan $50.7 \%$ dengan standar eror $18.4,16.1,31.8$, dan $32.5 \%$. Ini berarti bahwa tambahan keterangan konsentrasi triiodotironin dan kortisol pada bulan ke-3 setelah diketahui keterangan tentang konsentrasi progesteron dan estradiol pada bulan ke-3 hanya meningkatkan koefisien determinasi yang tidak nyata untuk DFFT, DNA, RNA, dan kolagen masing-masing 0.2 , 61,16 , dan $4.2 \%$ Demikian pula tambahan keterangan konsentrasi $\mathrm{B}-\mathrm{OH}$ butirat (BHBA) dan BUN pada bulan ke-3 setelah diketahui keterangan tentang konsentrasi progesteron dan estradiol pada bulan ke-3 akan meningkatkan koefisien determinasi untuk DFFT, DNA, RNA, dan kolagen masingmasing menjadi $92.3,94.1,89.3$, dan $55.0 \%$ dengan standar eror $15.6,11.1,21.3$, dan $31.3 \%$. Ini berarti bahwa tambahan keterangan konsentrasi $\mathrm{BO}-\mathrm{OH}$ butirat (BHBA) dan BUN pada bulan ke-3 setelah diketahui keterangan tentang konsentrasi progesteron dan estradiol pada bulan ke-3 hanya meningkatkan koefisien determinasi yang tidak nyata untuk DFFT, DNA, RNA, dan kolagen masing-masing $3.3,7.8,5.4$, dan $8.5 \%$.

Berdasarkan hasil tersebut di atas, ternyata penggunaan keterangan konsentrasi progesteron dan estradiol pada bulan ke-3 sudah cukup baik untuk memprediksi DFFT, DNA, dan RNA kelenjar susu masing-masing dengan koefisien determinasi $89.0,86.3$, dan $83.9 \%$ serta standar eror 16.8, 19.5, dan
$30.3 \%$. Namun untuk memprediksi kolagen kelenjar susu selain keterangan konsentrasi progesteron dan estradiol pada bulan ke-3 masih diperlukan tambahan keterangan konsentrasi kedua hormon tersebut pada bulan ke-4 sehinga diperoleh koefisien determinasi $68.3 \%$ dengan standar eror $23.4 \%$. Ini berarti bahwa konsentrasi progesteron dan estradiol pada bulan ke-3 dan atau ke-4 kebuntingan mempunyai hubungan yang erat dengan massa total, populasi sel, dan aktivitas sintesis kelenjar susu, sedangkan jaringan ikat pembuluh kelenjar susu pada awal laktasi lebih baik diprediksi oleh keterangan konsentrasi progesteron bulan ke-3 dan ke-4 kebuntingan. Dengan kata lain bahwa peningkatan konsentrasi progesteron dan estradiol pada bulan ke-3 dan atau bulan ke-4 kebuntingan akan menentukan pertumbuhan kelenjar susu pada awal laktasi. Peningkatan yang pesat kedua hormon tersebut pada bulan ke-3 berkaitan erat dengan proses plasentasi (Convey, 1974, Tucker, 1987). Pada domba, plasenta juga berfungsi sebagai kelenjar penghasil progesteron dan estradiol yang sekresinya akan meningkat drastis selama periode plasentasi (Ricketts dan Flint, 1980; Sheldrick et al, 1981; Forsyth, 1986; Sumaryadi dan Manalu, 1995b; Sumaryadi dan Manalu, 1996; Manalu, 1998). Progesteron akan meningkatkan percabangan dan pembentukan lobul alveolar (Anderson, 1985) setelah pemanjangan saluran kelenjar susu dirangsang oleh estradiol (Wright dan Anderson, 1982; Anderson, 1985; Wahab dan Anderson, 1989).

Selain keterangan konsentrasi progesteron dan estradiol pada bulan ke-3, ternyata secara parsial banyaknya anak yang dilahirkan berpengaruh sangat nyata $(\mathrm{P}<0.01)$ terhadap DFFT, DNA, dan RNA, dan kolagen kelenjar susu. Hasil ini menunjukkan bahwa konsentrasi progesteron dan estradiol yang tinggi pada induk yang beranak kembar akan menentukan pertumbuhan kelenjar susu pada awal laktasi. Pada domba telah dilaporkan bahwa jumlah anak berkorelasi dengan angka ovulasi (Bradford et al., 1986). Semakin 
banyak folikel yang diovulasikan, ketersediaan korpus luteum sebagai sumber penghasil progesteron dan estradiol akan semakin banyak. Kenyataan ini memberikan petunjuk bahwa peningkatan konsentrasi progesteron dan estradiol dalam serum induk bunting yang bisa dilakukan melalui superovulasi (Manalu et al., 1998) atau dengan penambahan secara eksogen, dapat digunakan untuk memperbaiki pertumbuhan dan perkembangan kelenjar susu dengan tujuan akhir produksi susu.

Pada umur kebuntingan 3 bulan atau 12 minggu, hubungan antara konsentrasi progesteron (PRO3) dan estradiol (EST3) dengan DFFT (g), DNA (mg), dan RNA (mg) kelenjar susu masing-masing mempunyai koefisien determinasi $89.0,86.3$, dan $83.6 \%$ dengan standar eror $16.8,19.5$, dan $30.3 \%$. Sedangkan kolagen memerlukan tambahan keterangan progesteron (PRO4) dan estradiol (EST4) pada bulan ke-4 dengan koefisien determinasi sebesar $68.3 \%$ serta standar eror $23.4 \%$ dan mengikuti persamaan regresi sebagai berikut.

1) Untuk induk dengan anak tunggal:

DFFT $=-26.7+4.1$ PRO3 +0.17 EST 3

DNA $=-1139+128$ PRO3 + 6.2 EST3

RNA $=-978+772$ PRO3 +12.6 EST3

Kolagen $=-361+17.4$ PRO3 +14.4

EST3 + 6.69 PRO4 + 7.40 EST4

2) Untuk induk dengan anak kembar 2 sampai 3 :

DFFT $=-22.5+4.1$ PRO3 + 0.17 EST 3

DNA $=-921+128$ PRO $3+6.20$ EST3

RNA $=-923+772$ PRO $3+12.6$ EST3

Kolagen $=-187+17.4$ PRO $3+14.4$ EST3 + 6.69 PRO4 + 7.40 EST 4

Hasil persamaan regresi tersebut dapat digambarkan menjadi suatu grafik hubungan antara DFFT, DNA, dan RNA kelenjar susu dengan konsentrasi progesteron pada bulan ke-3 kebuntingan berdasarkan pada rataan kadar estradiol induk beranak tunggal $(9.87$ $\mathrm{pg} / \mathrm{ml})$ dan kembar 2 sampai $3(15.16 \mathrm{pg} / \mathrm{ml})$ pada bulan ke-3, seperti disajikan pada Gambar 2. Grafik tersebut menunjukkan bahwa pada konsentrasi progesteron yang sama, komponen kimia kelenjar susu awal laktasi akan semakin tinggi, jika konsentrasi estradiol juga tinggi terutama pada induk yang beranak kembar. Dengan demikian, progesteron dan estradiol pada bulan ke-3 kebuntingan berperan penting terhadap pertumbuhan dan perkembangan kelenjar susu awal laktasi.

Keterangan tentang konsentrasi hormon dan metabolit darah pada bulan ke-1 kebuntingan belum dapat dipakai untuk memprediksi involusi kelenjar susu pada akhir laktasi dan produksi susu pada waktu laktasi $(P>0.05)$. Karena itu usaha memprediksi involusi kelenjar susu dan produksi susu dilakukan dengan menggunakan keterangan tentang konsentrasi hormon dan metabolit darah bulanan, masing-masing pada bulan ke-2, ke-3, dan ke-4 kebuntingan.

Komponen kimia kelenjar susu diukur melalui indikator bahan kering bebas lemak (DFFT), DNA, RNA, dan kolagen. Rataan indikator kimia pertumbuhan kelenjar susu pada akhir laktasi berdasarkan banyaknya anak yang dilahirkan atau disusui disajikan pada Tabel 4. Secara umum nilai rataan seluruh indikator komponen kimia kelenjar susu (Tabel 4) maupun produksi susu (Gambar 3) meningkat berdasarkan banyaknya anak yang dilahirkan. Hal ini tidak terlepas dari peranan hormon, tenutama progesteron dan estradiol yang sekresinya meningkat pesat pada induk yang melahirkan anak kembar (Manalu et al., 1996; Manalu, 1998) dalam perangsangan pertumbuhan kelenjar susu (Manalu dan Sumaryadi, 1998a) yang diikuti dengan peningkatan produksi susu. Gambar 3 menunjukkan bahwa produksi susu pada bulan ke-1 laktasi cukup tinggi baik pada induk yang beranak tunggal maupun kembar, dan cenderung menurun sampai bulan ke-3 laktasi Produksi susu yang tinggi pada bulan ke-1 laktasi berperan sangat penting sebagai sumber nutrisi utama bagi anak yang baru lahir, sehingga perlu dilihat hubungannya dengan hormon yang mempengaruhi pertumbuhan maupun involusi kelenjar susu. 

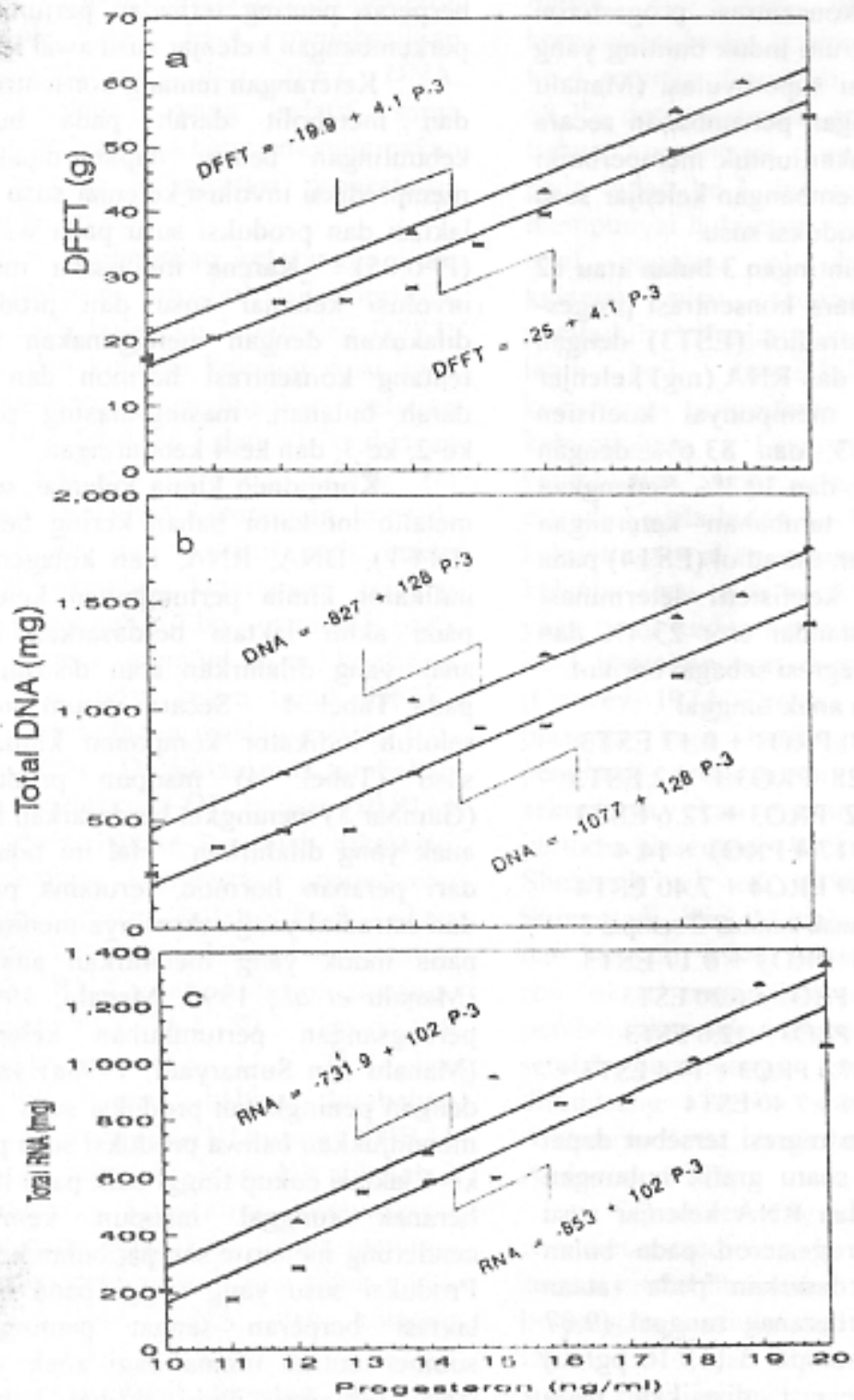

Gambar 2.Hubungan antara konsentrasi progesteron bulan ke-3 (P-3) dengan DFFT

(a), total DNA (b), dan total RNA (c) pada konsentrasi estradiol bulan ke-3 pada induk yang beranak tunggal ( $($ ) ) dan anak kembar $(\Delta)$. 


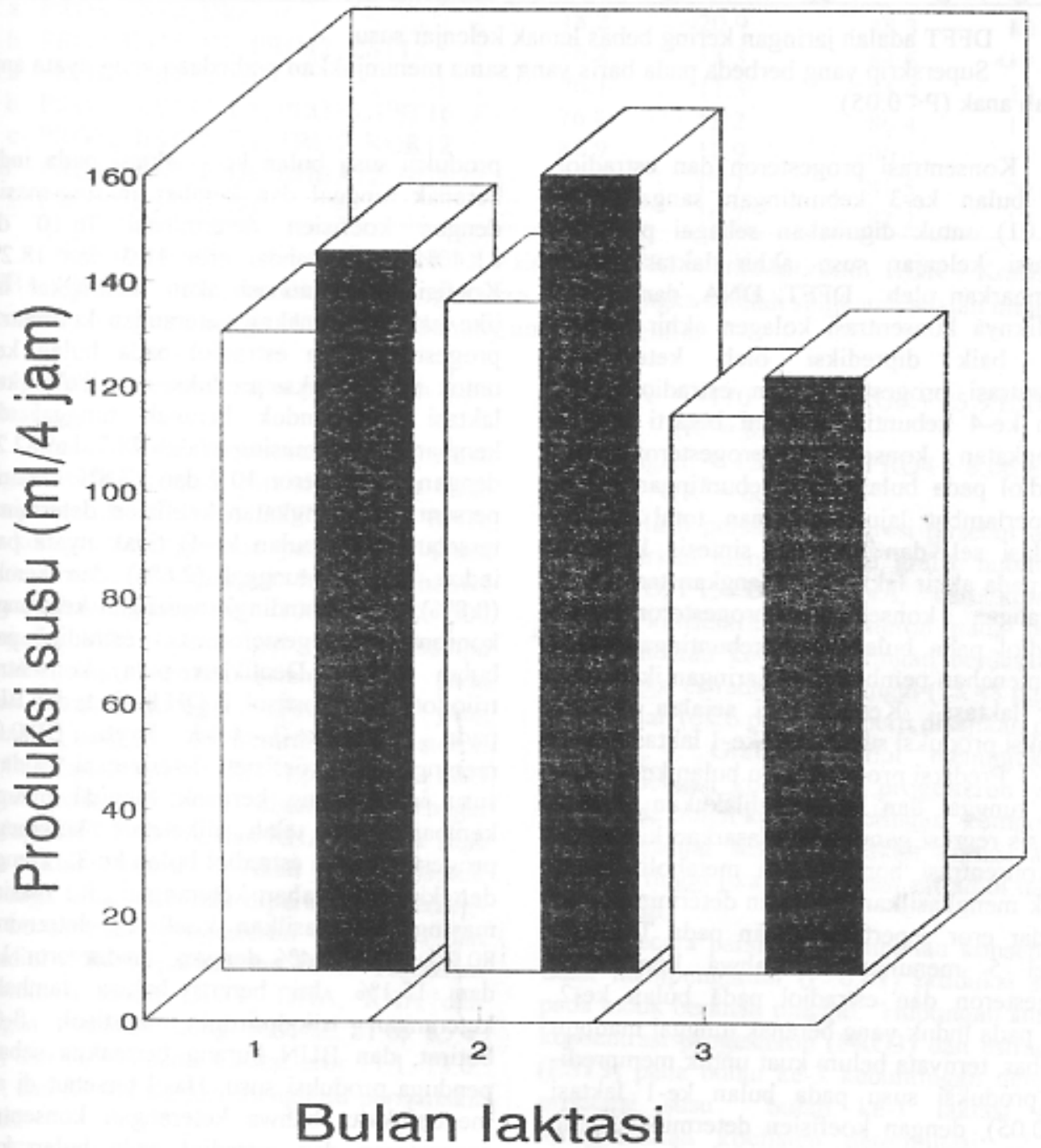

Gambar 3. Produksi susu induk domba yang melahirkan anak tunggal ( $\square$ ) dan kembar 2-3 ( $\square$ ) pada bulan laktasi ke-1, 2, dan 3 . 
Tabel 4. Rataan DFFT, DNA, RNA, dan kolagen kelenjar susu pada akhir laktasi berdasarkan jumlah anak yang dilahirkan

\begin{tabular}{|c|c|c|c|}
\hline \multirow{2}{*}{$\begin{array}{l}\text { Komponen kimia } \\
\text { kelenjar susu }\end{array}$} & \multicolumn{3}{|c|}{ Jumlah anak yang dilahirkan (ekor) } \\
\hline & Kosong $(0)$ & Tunggal (1) & Kembar (2 - 3) \\
\hline DFFT, $g^{1}$ & $2.12 \pm 0.26^{b}$ & $15.44 \pm 1.03^{\mathrm{a}}$ & $16.63 \pm 1.68^{\mathrm{n}}$ \\
\hline DNA, mg & $83.54 \pm 14.94^{\mathrm{b}}$ & $\pm 49.43^{\mathrm{a}}$ & $679.31 \pm 79.74^{2}$ \\
\hline RNA, mg & $27.29 \pm 4.44^{\mathrm{b}}$ & $\pm 29.39^{2}$ & $\pm 42,80^{\mathrm{a}}$ \\
\hline Kolagen, mg & $106.75 \pm 13.89^{b}$ & $377.49 \pm 46.20^{\mathrm{a}}$ & $389.97 \pm 47.97^{*}$ \\
\hline
\end{tabular}

1 DFFT adalah jaringan kering bebas lemak kelenjar susu.

${ }^{a, b}$ Superskrip yang berbeda pada baris yang sama menunjukkan perbedaan yang nyata antar jumlah anak $(\mathrm{P}<0.05)$.

Konsentrasi progesteron dan estradiol pada bulan ke-3 kebuntingan sangat kuat $(\mathrm{P}<0.01)$ untuk digunakan sebagai penduga involusi kelenjar susu akhir laktasi yang digambarkan oleh, DFFT, DNA, dan RNA. Sebaliknya konsentrasi kolagen akhir laktasi lebih baik diprediksi oleh keterangan konsentrasi progesteron dan estradiol pada bulan ke-4 kebuntingan. Ini berarti bahwa peningkatan konsentrasi progesteron dan estradiol pada bulan ke-3 kebuntingan dapat memperlambat laju penurunan total massa, populasi sel, dan aktivitas sintesis kelenjar susu pada akhir laktasi. Sedangkan tambahan keterangan konsentrasi progesteron dan estradiol pada bulan ke-4 kebuntingan akan bisa menahan pembentukan jaringan ikat pada akhir laktasi. Keadaan ini sejalan dengan prediksi produksi susu bulan ke-1 laktasi.

Prediksi produksi susu bulan ke-1 pada anak tunggal dan kembar dilakukan dengan analisis regresi ganda. Berdasarkan keterangan konsentrasi hormon dan metabolit darah induk menghasilkan koefisien determinasi dan standar eror seperti disajikan pada Tabel 5 . Tabel 5 menunjukkan bahwa konsentrasi progesteron dan estradiol pada bulan ke-2, baik pada induk yang beranak tunggal maupun kembar, ternyata belum kuat untuk memprediksi produksi susu pada bulan ke-1 laktasi $(\mathrm{P}>0.05)$, dengan koefisien determinasi yang masih rendah. Akan tetapi, konsentrasi progesteron dan estradiol pada bulan ke-3 saja sangat kuat $(\mathrm{P}<0.01)$ serbagai penduga produksi susu bulan ke-1 laktasi pada induk beranak tunggal dan kembar masing-masing dengan koefisien determinasi 76.10 dan $81.40 \%$ serta standar eror 11.3 dan $18.2 \%$. Koefisien determinasi akan meningkat lagi jika hanya digunakan keterangan konsentrasi progesteron dan estradiol pada bulan ke-4 untuk memprediksi produksi susu bulan ke-1 laktasi pada induk beranak tunggal dan kembar masing-masing adalah 78.7 dan $82.2 \%$ dengan standar eror 10.7 dan $17.8 \%$. Namun persentase peningkatan koefisien determinasi tersebut (pada bulan ke-4) tidak nyata pada induk beranak tunggal (2.6\%) dan kembar $(0.8 \%)$, jika dibandingkan dengan keterangan konsentrasi progesteron dan estradiol pada bulan ke-3. Demikian pula, konsentrasi triiodotironin, kortisol, $\mathrm{B}-\mathrm{OH}$ butirat, dan BUN pada bulan ke-3 tidak nyata $(\mathrm{P}>0.05)$ meningkatkan koefisien determinasi produksi susu induk yang beranak tunggal maupun kembar, jika telah diketahui keterangan progesteron dan estradiol bulan ke-3. Dengan demikian, tambahan keterangan itu masingmasing menghasilkan koefisien determinasi 80.94 dan $90.04 \%$ dengan standar eror 11.9 dan $15.1 \%$. Ini berarti bahwa tambahan keterangan triiodotironin, kortisol, $\mathrm{B}-\mathrm{OH}$ butirat, dan BUN kurang bermakna sebagai penduga produksi susu. Hasil tersebut di atas menunjukkan bahwa keterangan konsentrasi progesteron dan estradiol pada bulan ke-3 kebuntingan sudah cukup kuat untuk 
Tabel 5. Koefisien determinasi $\left(\mathrm{R}^{2}\right)$ dan standar error (SE) rataan produksi susu (ml/4 jam) bulan ke-1 laktasi pada induk beranak tunggal dan kembar 2-3 berdasarkan konsentrasi hormon dan metabolit dalam darah induk selama kebuntingan

\begin{tabular}{|c|c|c|c|c|}
\hline \multirow{3}{*}{ Hormon/Metabolit $^{1}$} & \multicolumn{4}{|c|}{ Jumlah anak (ekor) } \\
\hline & \multicolumn{2}{|c|}{ Tunggal } & \multicolumn{2}{|c|}{ Kembar } \\
\hline & $\mathbf{R}^{2}$ & SE & $\mathrm{R}^{2}$ & SE \\
\hline & & & & \\
\hline 1.a. PRO8, EST8, Dk & 18.2 & 20.9 & 48.3 & 30.3 \\
\hline b. PRO8, EST8, Dk, PRO12, ESTI2 & 76.2 & 13.3 & 83.6 & 19.4 \\
\hline 2.a. PRO12, EST12, Dk & 76.1 & 11.3 & 81.4 & 18.2 \\
\hline b. PRO12, EST12, Dk, PRO16, EST16 & 76.8 & 13.2 & 86.4 & 17.7 \\
\hline c. PRO12, EST12, Dk, TRI12, KOR 12 & 80.9 & 11.9 & 90.1 & 15.1 \\
\hline d. PRO12, EST 12, Dk, BHBA12, BUN 12 & 78.5 & 12.7 & 81.5 & 20.6 \\
\hline 3.a. PRO16, EST16, Dk & 78.7 & 10.7 & 82.2 & 17.8 \\
\hline
\end{tabular}

'Konsentrasi PRO = Progesteron; EST $=$ Estradiol; TRI $=$ Triiodotironin, $\mathrm{KOR}=$ Kortisol; $\mathrm{BHBA}=\beta-\mathrm{OH}$ butirat; dan $\mathrm{BUN}=$ Nitrogen urea darah. Angka setelah singkatan adalah umur kebuntingan dalam minggu. Dk adalah dummy untuk konsentrat.

memprediksi produksi susu pada bulan ke-1 laktasi.

Penambahan konsentrat yang ditelaah dengan analisis regresi parsial, ternyata tidak mempengaruhi ( $P>0.05$ ) DFFT, DNA, RNA, dan kolagen kelenjar susu pada akhir laktasi induk yang beranak tunggal. Ini berarti bahwa penambahan konsentrat $100 \%$ dari 500 menjadi $1000 \mathrm{~g} / \mathrm{ekor} / \mathrm{hari}$ tidak mampu menahan laju involusi kelenjar susu pada induk beranak tunggal Pada induk yang beranak tunggal, konsentrasi progesteron (PRO3) dan estradiol (EST3) pada bulan ke-3 sangat baik $(P<0.01)$ digunakan sebagai penduga DFFT, DNA, dan RNA kelenjar susu pada akhir laktasi. Akan tetapi, untuk menduga kolagen masih diperlukan keterangan konsentrasi progesteron (PRO4) dan estradiol (PRO4) pada bulan ke-4. Koefisien determinasi untuk DFFT, DNA, RNA dan kolagen masing-masing sebesar 81.0, 85.4, 83.7 , dan $66.9 \%$ serta standar eror $11.1,13.0$, 15.9 , dan $28.4 \%$ dengan mengikuti persamaan regresi;

$$
\begin{aligned}
& \begin{aligned}
\text { DFFT } & =-3.29+0.76 \mathrm{PRO} 3+0.62 \text { EST3 }\left(\mathrm{R}^{2}\right. \\
& =81.0 \%)
\end{aligned} \\
& \text { DNA }=-409+51.3 \text { PRO3 + 16.4 EST3 } \\
& \left(R^{2}=85,4 \%\right)
\end{aligned}
$$

$$
\begin{gathered}
\text { RNA }=-170+12.1 \text { PRO3 + 25.9 EST3 } \\
\left(R^{2}=83.7 \%\right) \\
\text { Kolagen }=125+15.5 \text { PRO4 + 8.06 EST4 } \\
\left(R^{2}=66.9 \%\right)
\end{gathered}
$$

Hasil persamaan regresi tersebut dapat digambarkan menjadi suatu grafik hubungan antara DFFT, DNA, RNA, dan kolagen dengan konsentrasi progesteron pada bulan ke-3 dan atau ke-4 kebuntingan berdasarkan konsentrasi estradiol yang tinggi $(13.48 \mathrm{pg} / \mathrm{ml})$ dan rendah $(6.26 \mathrm{pg} / \mathrm{ml})$, seperti disajikan pada Gambar 4. Grafik tersebut menunjukkan bahwa dengan konsentrasi progesteron yang sama pada bulan ke-3 kebuntingan, komponen kimia kelenjar susu pada akhir laktasi akan semakin tinggi jika konsentrasi estradiol induk juga tinggi.

Secara parsial, penambahan konsentrat tidak mempengaruhi $(\mathrm{P}>0.05)$ produksi susu pada induk beranak tunggal. Hubungan antara konsentrasi progesteron (PRO3) dan estradiol (EST3) pada bulan ke-3 kebuntingan dengan produksi susu bulan ke-1 laktasi (Y) menghasilkan koefisien determinasi $72.3 \%$ dan standar eror 11.5, dengan mengikuti persamaan regresi:

$$
\begin{gathered}
-61.8+8.47 \\
72.3 \%)
\end{gathered} \text { PRO3 + 4.79 EST3 } \quad\left(\mathrm{R}^{2}=\right.
$$



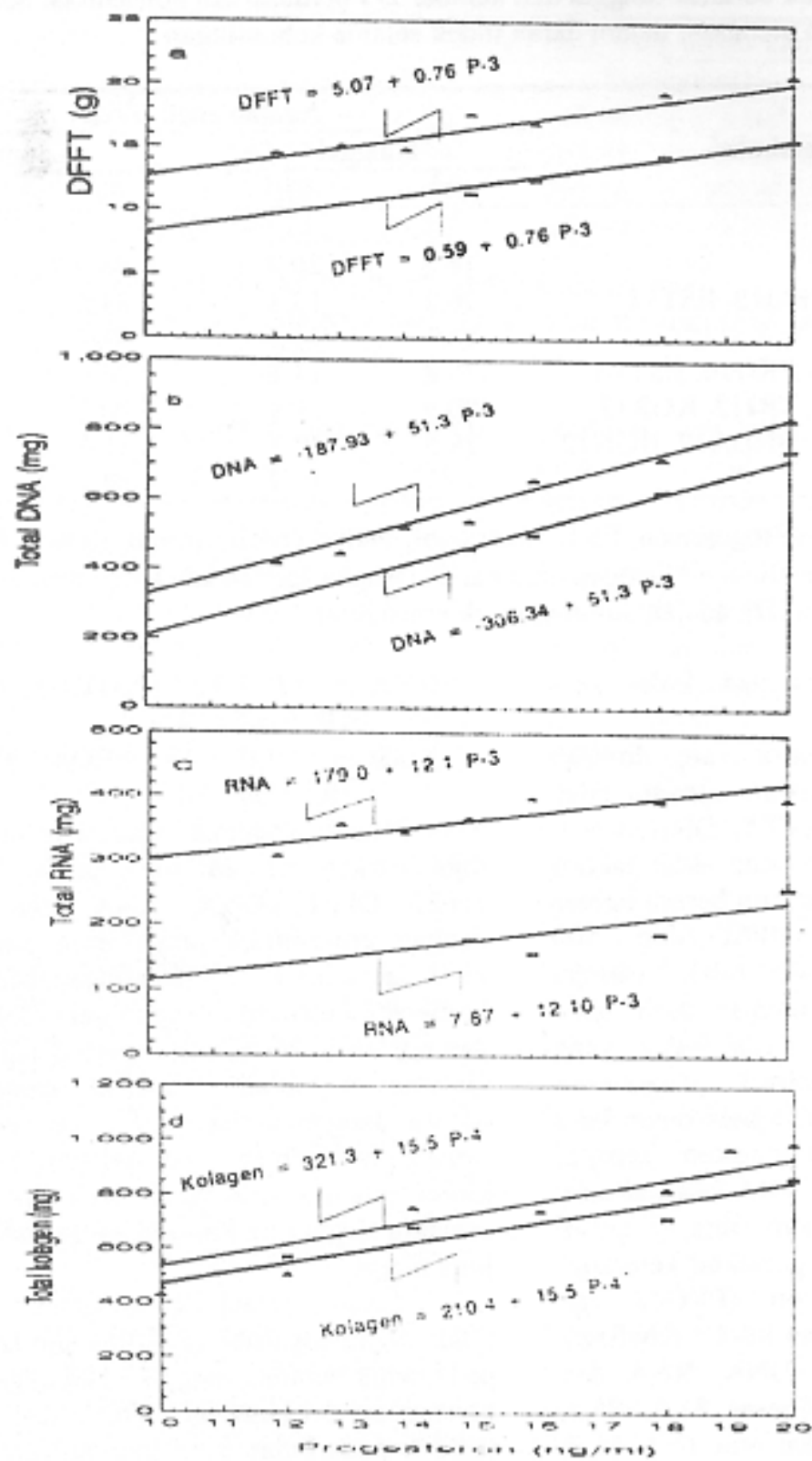

Gambar 4. Hubungan antara konsentrasi progesteron pada kebuntingan 3 atau 4 bulan (P-3 atau $P-4)$ dengan jaringan kering bebas lemak kelenjar susu (DFFT) (a), DNA (b), RNA (c) dan kolagen (d) pada akhir laktasi pada induk beranak tunggal berdasarkan kadar estradiol rendah (*) dan tinggi $(\Delta)$. 
Ini berarti bahwa penambahan konsentrat $100 \%$ dari 500 menjadi $1000 \mathrm{~g} /$ ekor/hari kurang bermakna pada induk yang menyusui anak tunggal. Dari hasil persamaan regresi tersebut dapat digambarkan menjadi suatu grafik hubungan antara produksi susu bulan ke-1 laktasi pada induk beranak tunggal dengan konsentrasi progesteron pada bulan ke-3 kebuntingan, berdasarkan pada konsentrasi estradiol tinggi $(13.48 \mathrm{pg} / \mathrm{ml})$ dan rendah $(6.26 \mathrm{pg} / \mathrm{ml})$, seperti disajikan pada Gambar 5 . Grafik tersebut menunjukkan bahwa pada konsentrasi progesteron yang sama, produksi susu pada bulan ke-1 laktasi akan semakin tinggi, jika konsentrasi estradiol pada bulan ke-3 juga tinggi dengan standar eror $11.3 \%$ dari rataan produksi bulan ke-1 laktasi

Sebaliknya pada induk yang beranak kembar 2-3, secara parsial konsentrat sangat nyata $(\mathrm{P}<0.01)$ menaikkan DFFT, DNA, RNA, dan kolagen kelenjar susu. Rataan komponen kelenjar susu akhir laktasi pada induk yang beranak kembar berdasarkan tingkat konsentrat, disajikan pada Tabel 6. Tabel. 6 menunjukkan bahwa penambahan konsentrat pada induk yang menyusui anak kembar mampu menahan laju penurunan DFFT, DNA, RNA, dan kolagen masing masing sebesar 52.69, $57.48,81.63$, dan $57.99 \%$.

Ini berarti bahwa penambahan konsentrat mampu memperlambat laju involusi kelenjar susu akhir laktasi, sehingga jaringan kelenjar susu yang pesat pada induk dengan anak kembar tidak akan bertahan lama jika tidak tersedia substrat yang mencukupi. Dengan demikian, peningkatan aktivitas sintetik sel-sel sekretoris (Djojosoebagio, 1965; Anderson, 1985) selama laktasi melalui peningkatan substrat (konsentrat) bisa memperlambat laju involusi, di samping peranan hormon hormon selama laktasi yang masih memerlukan kajian lebih lanjut.

Pada induk yang beranak kembar, hubungan antara progesteron (PRO3 atau PRO4) dan estradiol (EST3 atau EST4) pada bulan ke-3 atau ke-4 dengan DFFT, DNA, RNA, dan kolagen masing-masing mempunyai koefisien determinasi sebesar 81.4, 77.9, 80.1. dan $69 \%$ serta standar eror $16.8,23.9,22.4$, dan $28.6 \%$ yang mengikuti persamaan regresi:

1) Untuk tingkat konsentrat $500 \mathrm{~g}$ : DFFT $=-0.79+0.62 \mathrm{PRO} 3+0.13 \mathrm{EST} 3$ DNA $=-405+35.5$ PRO $3+12.6$ EST 3 RNA $=-124+18.0$ PRO $3+1.94$ EST 3 Kolagen $-155+3.54$ PRO4 +4.61 EST4

2) Untuk tingkat konsentrat $1000 \mathrm{~g}$.

DFFT $=5.62+0.62 \mathrm{PRO} 3+0.13 \mathrm{EST} 3$

DNA $=-306+35.5$ PRO $3+12.6$ EST3

RNA $=43+18.0$ PRO3 + 1.94 EST3

Kolagen $=\mid 60.1+3.54$ PRO4 + 4.61 EST 4

Hasil persamaan regresi tersebut dapat digambarkan menjadi suatu grafik hubungan antara DFFT, DNA, RNA, dan kolagen dengan konsentrasi progesteron pada bulan ke-3 atau ke-4 kebuntingan berdasarkan pada rataan konsentrasi estradiol induk yang diberi

Tabel 6, Rataan DFFT, DNA, RNA, dan kolagen kelenjar susu pada akhir laktasi pada induk yang beranak kembar 2-3 berdasarkan tingkat pemberian konsentrat

\begin{tabular}{|c|c|c|c|c|}
\hline \multirow{3}{*}{ Indeks kelenjar susu } & \multicolumn{4}{|c|}{ Tingkat pemberian konsentrat } \\
\hline & \multicolumn{2}{|c|}{$500 \mathrm{~g}$} & \multicolumn{2}{|c|}{$1000 \mathrm{~g}$} \\
\hline & 13.57 & $1.41^{b}$ & 20.72 & $\pm \quad 2.04^{\mathrm{a}}$ \\
\hline DNA, mg & $499.81=$ & $85.12^{b}$ & 787.09 & $\pm 122.22^{\mathrm{a}}$ \\
\hline RNA, mg & $237.45=$ & $=34.99^{\mathrm{b}}$ & 431.29 & $\pm 71.06^{\mathrm{A}}$ \\
\hline Kolagen, mg & $257.18+$ & $=35.72^{\mathrm{b}}$ & 406.34 & $55.49^{3}$ \\
\hline
\end{tabular}

${ }^{1}$ DFFT adalah berat kering bebas lemak jaringan kelenjar susu.

${ }^{a, b}$ Superskrip yang berbeda pada baris yang sama menunjukkan perbedaan yang nyata pada tingkat pemberian konsentrat $(\mathrm{P}<0.05)$. 


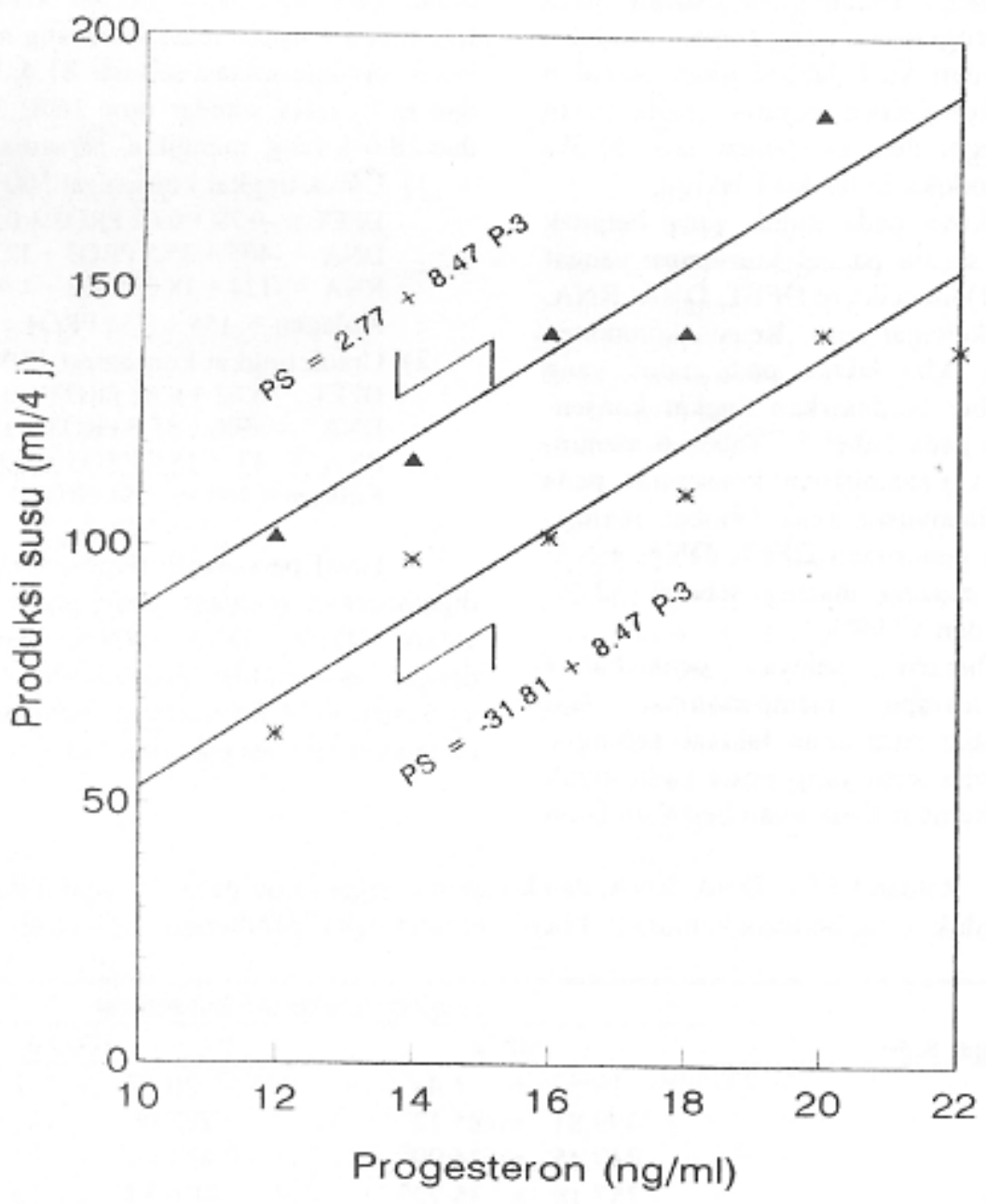

Gambar 5 . Hubungan antara konsentrasi progesteron pada kebuntingan 3 (P-3) dengan produksi susu (PS) pada induk beranak tunggal berdasarkan kadar estradiol rendah (*) dan tinggi $(\Delta)$. 
konsentrat $500 \mathrm{~g}(12.5 \mathrm{pg} / \mathrm{ml})$ dan $1000 \mathrm{~g}$ $(14.5 \mathrm{pg} / \mathrm{ml})$, seperti disajikan pada Gambar 6 . Grafik tersebut menunjukkan bahwa pada konsentrasi progesteron yang sama, komponen kimia kelenjar susu akhir laktasi akan semakin tinggi jika konsentrasi estradiol juga tinggi terutama pada induk beranak kembar yang diberi konsentrat $1000 \mathrm{~g}$. Ini berarti bahwa laju involusi kelenjar susu akhir laktasi semakin menurun jika konsentrasi progesteron dan estradiol semakin tinggi. Dengan demikian, konsentrasi progesteron dan estradiol pada bulan ke-3 dan 4 kebuntingan dan ketersediaan substrat sangat menentukan laju involusi kelenjar susu pada induk beranak kembar.

Di samping itu, pada induk yang beranak kembar, ternyata level penambahan konsentrat sangat nyata $(\mathrm{P}<0.01)$ mempengaruhi produksi susu bulan ke-1 laktasi. Hubungan antara progesteron (PRO3) dan estradiol (PRO3) bulan ke-3 dengan produksi susu bulan ke-1 laktasi (PS1), mempunyai koefisien determinasi $81.4 \%$ dengan standar eror $18.2 \%$ dan mengikuti persamaan regresi masing-masing untuk tingkat konsentrat 500 dan $1000 \mathrm{~g}$ sebagai berikut:

1) untuk tingkat konsentrat $500 \mathrm{~g} / \mathrm{ekor} / \mathrm{hari}$ PS1 $=-79.5+5.07$ PRO3 + 6.87 EST3

2) untuk tingkat konsentrat $1000 \mathrm{~g} /$ ckor/hari PSI $=-36.1+5.07$ PRO $3+6.87$ EST3

Ini berarti bahwa penambahan konsentrat 100 $\%$ dari 500 menjadi $1000 \mathrm{~g} /$ ekor/hari sangat bermanfaat untuk meningkatkan produksi susu pada induk yang beranak kembar. Hasil persamaan regresi tersebut dapat digambarkan menjadi suatu grafik hubungan antara produksi susu bulan ke-1 laktasi dengan konsentrasi progesteron pada bulan ke-3 berdasarkan pada rataan konsentrasi estradiol induk yang diberi konsentrat $500 \mathrm{~g}$ (12.5 $\mathrm{pg} / \mathrm{ml})$ dan $1000 \mathrm{~g}(14.5 \mathrm{pg} / \mathrm{ml})$, seperti disajikan pada Gambar 7. Grafik tersebut menunjukkan bahwa pada konsentrasi progesteron yang sama, produksi susu pada bulan ke-l laktasi akan semakin tinggi, jika konsentrasi estradiol juga tinggi terutama pada induk beranak kembar yang diberi konsentrat $1000 \mathrm{~g}$ dengan standar eror $18.2 \%$ dari rataan produksi susu bulan ke-1 laktasi.

Rataan produksi susu pada induk yang beranak kembar adalah $108 \pm 4.4 \mathrm{ml} / 4$ jam untuk yang diberi konsentrat $500 \mathrm{~g} / \mathrm{ekor} / \mathrm{hari}$ dan $160.51 \pm 21.9 \mathrm{ml} / 4$ jam untuk yang diberi konsentrat $1000 \mathrm{~g} / \mathrm{ekor} / \mathrm{hari}$ atau meningkat sebesar $48.62 \%$. Berdasarkan hal tersebut jelas terlihat bahwa produksi susu yang dihasilkan tetap konsisten dengan gambaran potensi pertumbuhan dan laju involusi kelenjar susu sebelumnya.

Hasil penelitian ini menunjukkan bahwa potensi pertumbuhan kelenjar susu awal laktasi pada induk yang beranak kembar tidak akan memberikan hasil produksi susu yang maksimal, jika tidak diikuti dengan ketersediaan substrat (perbaikan nutrisi induk) untuk meningkatkan aktivitas sintesis dan memperlambat laju involusi kelenjar susu akhir laktasi.

\section{Kesimpulan dan Saran}

Konsentrasi progesteron dan estradiol pada bulan ke-3 dan atau ke-4 kebuntingan dapat digunakan untuk memprediksi komponen kelenjar susu pada awal laktasi dengan kisaran koefisien determinasi antara 66.9 dan $89.0 \%$. Untuk meningkatkan produksi susu induk, perlu dikaji lebih lanjut pengaruh peningkatan sekresi progesteron dan estradiol endogen hasil superovulasi terhadap pertumbuhan dan perkembangan kelenjar susu (Manalu et al., 1998) pada berbagai fase kebuntingan dengan menggunakan domba percobaan yang lebih banyak.

Konsentrasi progesteron dan estradiol pada bulan ke-3 atau ke-4 kebuntingan dapat digunakan untuk memprediksi komponen kelenjar susu pada akhir laktasi, serta produksi susu pada bulan ke-1 laktasi dengan kisaran koefisien determinasi antara 66.9 dan $89.0 \%$. Penambahan konsentrat $100 \%$ dari $500 \mathrm{~g}$ menjadi $1000 \mathrm{~g} /$ ekor/hari sangat nyata untuk menahan laju involusi DFFT, DNA, RNA, dan kolagen kelenjar susu masing-masing 52.69 , $57.48,81.63$, dan $57.99 \%$, serta meningkatkan produksi susu induk terutama pada induk 


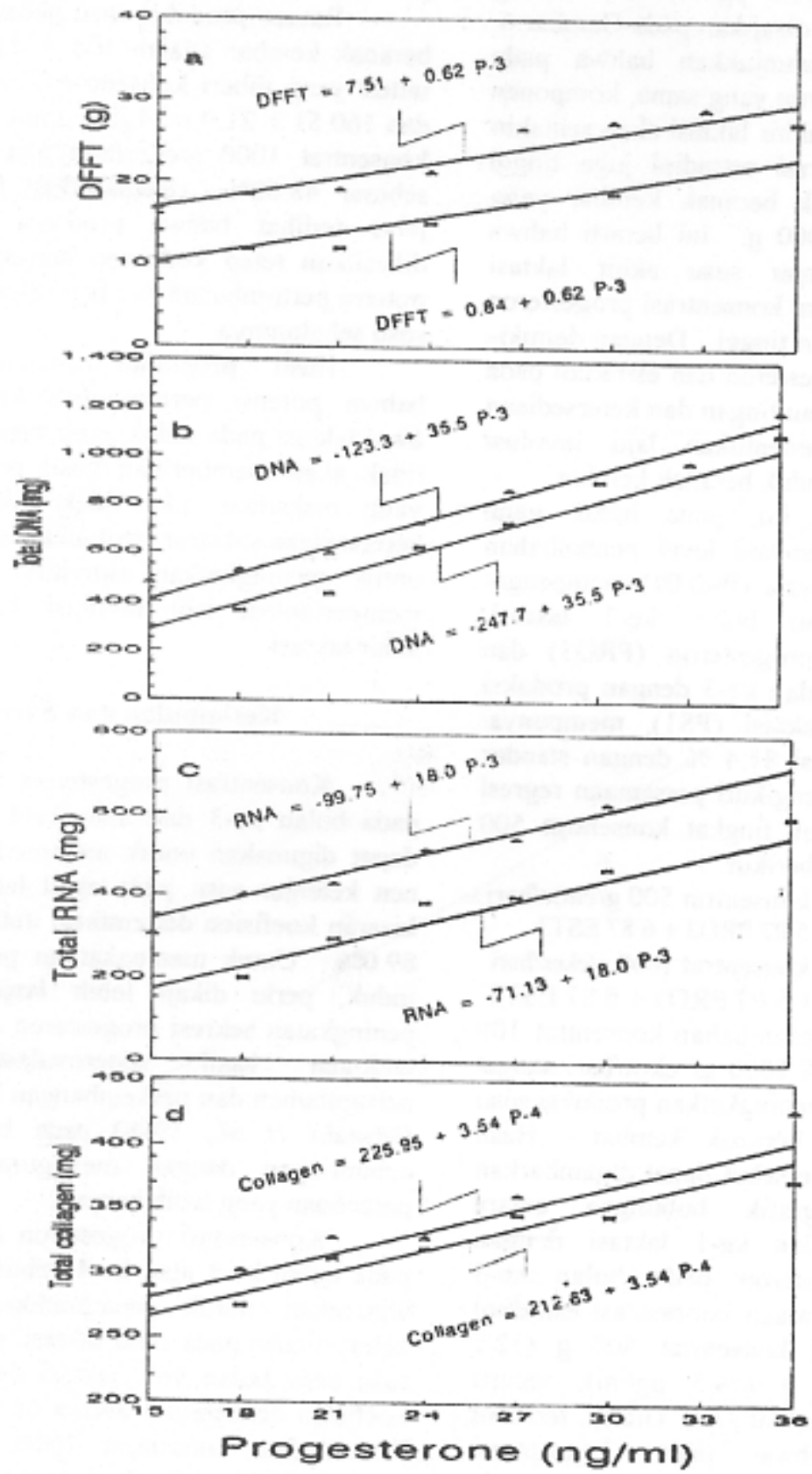

Gämbar 6.Hubungan antara konsentrasi progesteron pada kebuntingan 3 atau 4 bulan (P-3 atau P-4) dengan jaringan kering bebas lemak kelenjar susu (DFFT) (a), DNA (b), RNA (c) dan kolagen

(d) pada akhir laktasi pada induk beranak kembar 2-3 berdasarkan tingkat pemberian konsentrat $500 \mathrm{~g}($ *) dan $1000 \mathrm{~g}(\Delta)$. 


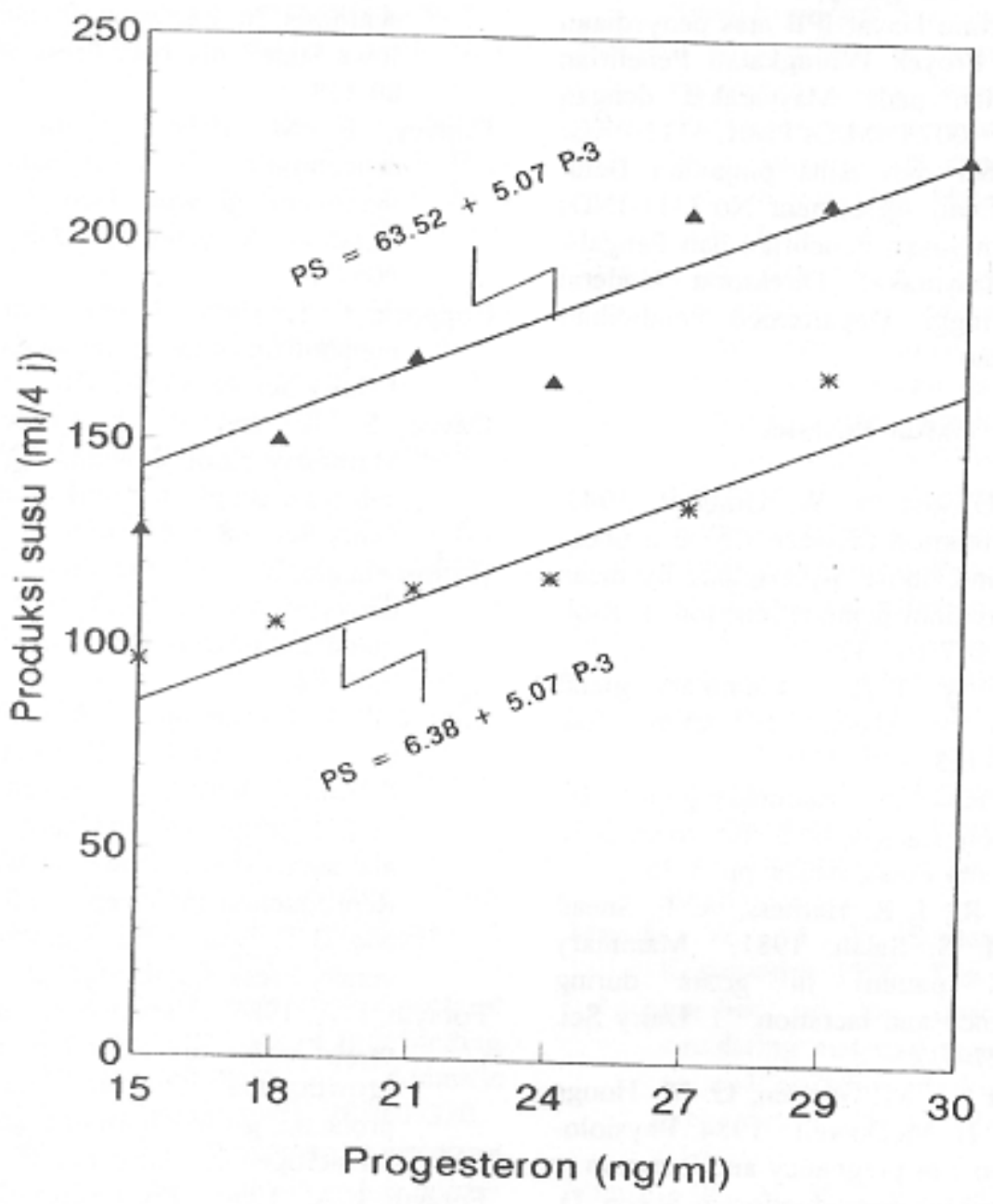

Gambar 7.Hubungan antara konsentrasi progesteron pada kebuntingan $3(\mathrm{P}-3)$ dengan produksi susu (PS) pada induk beranak kembar $2-3$ berdasarkan tingkat pemberian konsentrat $500 \mathrm{~g}($ 妻) dan $1000 \mathrm{~g}(\Delta)$. 
beranak kembar sebesar $48.62 \%$.

Penambahan konsentrat (substrat) sampai $1000 \mathrm{~g} / \mathrm{ekor} / \mathrm{hari}$ dapat dilakukan mulai awal bulan laktasi terutama pada induk yang menyusui anak kembar untuk menahan laju involusi kelenjar susu dan meningkatkan produksi susu guna meningkatkan bobot sapih anak kembar

\section{Ucapan Terima Kasih}

Penulis mengucapkan terima kasih kepada PAU-IImu Hayat IPB atas penyediaan dana melalui Proyek Peningkatan Penelitian dan Pengabdian pada Masyarakat dengan kontrak No. 007/P4M/DPPM/L.3311/PAU/ 1993 bersumber dari dana pinjaman Bank Dunia XXI (Loan Agreement No.3311-IND) Direktorat Pembinaan Penelitian dan Pengabdian pada Masyarakat, Direktorat Jenderal Pendidikan Tinggi, Departemen Pendidikan dan Kebudayaan

\section{Daftar Pustaka}

Albaum, H. G. and W. W. Umbreit. 1947. Differentiation between ribose 3-phosphate and ribose 5-phosphate by mean of the orcinol pentose reaction. J. Biol. Chem. 167:167-373

Anderson, R. R. 1975. Mammary gland growth in sheep. J. Anim. Sci. 41:118-123.

Anderson, R. R. 1985. Mammary gland. In Lactation. Larson, B. L. Ed. Iowa State University Press, Ames. pp. 3-38.

Anderson, R. R., J. R. Harness, A. F. Snead and M S. Salah. 1981. Mammary growth pattern in goats during pregnancy and lactation. J. Dairy Sci. $64: 427-432$.

Annison, E. F., J. M. Gooden, G. M. Houge and G. H. McDowell, 1984. Physiological cost of pregnancy and lactation in the ewe. In: Reproduction in Sheep. D. R. Lindsay, D. T. Pearce Ed. Cambridge University Press, Cambridge. pp. 174-181.
Bradford, G. E. 1985. Selection for litter sizes.

In: Genetics of Reproduction in Sheep.

R. B. Land and D.W. Robinson Ed. Butterworth, London. pp. 3-18.

Bradford, G. E, J. F. Quirke, P. Sitorus, I. Inounu, B. Triesnamurti, F. L. Bell, I C. Flitcher and D. T. Torrel. 1986 Reproduction in Javanese Sheep: Evidence for gene with large effect on ovulation rate and lamb survival. $\mathbf{J}$. Anim. Sci. 63:418-431.

Collier, R. J. 1985. Nutritional control of milk synthesis. In: Lactation. Larson, B. Ed. lowa State University Press, Ames. pp. 80-128

Convey, E. M 1974. Serum hormone concentration in ruminant during mammary growth, lactogenesis, and lactation: A review. J. Dairy Sci. 57: 905-917

Coppock, C. E. 1985. Energy nutrition and metabolism of the lactating dairy cows. J Dairy Sci. 68:3403-3410.

Davis, S. R. and R. J. Collier 1983. Mammary blood flow and regulation of substrate supply for milk synthesis. J. Dairy Sci. 68:1041-1058.

Djojosoebagio, S. 1965. Relationship between deoxyribonucleic acid of mammary gland and its milk secretion. Com. Vet. 9:40-47.

Foot, J. Z, L. J. Cummins, S. A Spiker and P. C. Flinn. 1984. Concentration of B-hydroxy buttyrate in plasma of ewes in late pregnancy and early lactation, and survival and growth of lambs. In: Reproduction in Sheep. D R. Lindsay and D.T. Pearce Ed. Cambridge University Press, Cambridge. pp. 187-190.

Forsyth, I. A. 1986. Variation among species in the endocrine control of mammary growth and function: The role of prolactin, growth hormone, and placental lactogen. J. Dairy. Sci. 69: 886-903.

Forsyth, I. A. 1996. The insulin-like growth factor and epidermal growth factor families in mammary cell growth in ruminants: Action and interaction with 
hormones. J. Dairy Sci. 79:1085-1096

Gemmell, R. T. 1995. A Comparative study of the corpus luteum. Reprod. Fertil. Dev. 7:303-12.

Harness, J. R and R. R. Anderson. 1977a. Effect of relaxin and somatotropin in combination with ovarians steroids on mammary gland in rats. Proc Soc. Exp. Biol. Med. 17:599-604.

Harness, J. R. and R. R. Anderson. 1977b. Effect of relaxin and somatotropin in combination with ovarians stereids on mammary growth in hypophysectomized rats. Proc. Soc. Exp. Biol. Med. 156:354-360.

Hayden, T. J., C. R. Thomas and I. A. Forsyth. 1979. Effect of number of young born (litter size) on milk yield of goat: Role of placental lactogen. J. Dairy Sci. 62:53-57

Imagawa, W., Y. Tomokai, S. Hamamoto and S. Nandi. 1985. Stimulation of mammary epithelial cell growth in vitro: Interaction of epidermal growth factor and mammogenic hormones. Endocrinology 116:1514-1524.

Imagawa, W., E. M. Spencer, L. Larson and S. Nandi. 1986. Soamtomedin C subtitutes for insulin for growth of mammary epithelial cells from normal virgin mice in serum free collagen gel cell culture. Endocrinology 119:2695-2699.

Jarrell, V. L. and P. J. Dziuk. 1991. Effect of number of corpora lutea and fetuses on concentrations of progesterone in blood of goats. J. Anim. Sci. 69:770-773.

Knight, C. H. and M. Peaker. 1982. Development of mammary gland. J. Reprod. Fertil. 65: 521-536.

Lindner, H. R. 1964. Comparative aspects of cortisol transport: Lack of firm binding to plasma protein in domestic ruminants. J. Endocrinol. 28:301-320.

Manalu, W. 1998. Perubahan konsentrasi progesteron dalam serum induk domba dari fase luteal ke fase plasental kebuntingan: pengaruh jumlah anak. Buletin Peternakan 22 (in press).
Manalu, W. and M. Y. Sumaryadi. 1998a. Maternal serum progesterone concentration during gestation and mammary gland growth and development at parturition in Javanese thin-tail ewes carrying a single or multiple fetuses. Small Ruminant Res. 27:131-136.

Manalu, W. and M. Y. Sumaryadi. $1998 \mathrm{~b}$. Maternal serum progesterone concentration during pregnancy and lamb birth weight at parturition in Javanese thintail ewes with different litter sizes Small Ruminant Res, (in press)

Manalu, W. dan M. Y. Sumaryadi. 1998c Perubahan status energi pada induk domba ekor tipis dengan bertambahnya umur kebuntingan dan jumlah fetus yang di kandung. Buletin Peternakan 22:8-13.

Manalu, W. dan M. Y. Sumaryadi. 1996. Konsentrasi triiodotironin dan kortisol dalam serum induk domba selama periode kebuntingan dan laktasi pada berbagai jumlah anak. Prosiding Seminar Nasional Peternakan dan Veteriner. Pusat Penelitian dan Pengembangan Peternakan, Badan Penelitian dan Pengembangan Pertanian, Departemen Pertanian. Halaman 957-962.

Manalu, W., M. Y. Sumaryadi and N Kusumorini. 1997. Maternal serum concentrations of total thriiodothyronine, tetraiodothyronine and cortisol in different status of pregnancy during late pregnancy in Ettawah-cross does. Asian-australasian J. Anim. Sci. 10:385-390.

Manalu, W., M. Y. Sumaryadi and N. Kusumorini. 1996. The effects of fetal number on the concentrations of circulating maternal serum progesterone and estradiol of does during late pregnancy. Small Ruminant Res. 23:117-124

Manalu, W., M. Y. Sumaryadi, Sudjatmogo and A. S. Satyaningtijas. 1998. Mammary gland differential growth during pregnancy in superovulated 
Javanese thin-tail ewes. Small Ruminant Res. (in press).

Paterson, J. Y. F. and F. A. Harrison. 1967. The specific activity of plasma cortisol in sheep during continous infusion of [1,2-3]cortisol and its relation to the rate of cortisol secretion. J. Endocrin. 37:269-277

Piper, L. R. and B. M. Bindon. 1984. Ovulation rate as selection criterion for improving litter size in Merino sheep. In: Reproduction in Sheep. D.R. Lindsay and D.T. Pearce Ed. Cambridge University Press, Cambridge. pp. 237-239.

Rattray, P. V., W. N. Garret, N. E. East and N. Hinman. 1974. Growth, development and composition of the ovine conceptus and mammary gland during pregnancy. J. Anim. Sci. 38:613-626.

Ricketts, A. P. and A. P. F. Flint. 1980. Onset of synthesis of progesterone by ovine placenta. J. Endocrin 86:337-347.

Sheffield, L. G. and R. R. Anderson. 1985 Relationship between milk production and mammary gland indices of guinea pigs. J. Dairy Sci. 68:638-645.

Sheldrick, E. L., A. P. Ricketts and A. P. F. Flint. 1981. Placental production of $5 \beta$-pregnane- $3 \alpha, 20 \alpha$-diol in goats. J, Endocrin. 90:151-158.

Sumaryadi, M. Y.and W. Manalu, 1995a. The effects of corpora luteal number on serum progesterone and estradiol of ewes during luteal phase of estrous cycle and pregnancy. Bull. Anim. Sci. Special Edition: 231-235

Sumaryadi, M. Y. dan W. Manalu. 1995b Peranan konsentrasi progesteron dalam serum induk selama periode kebuntingan dalam mendukung keberhasilan reproduksi: Pengaruh pada pertumbuhan fetus, kelenjar susu, produksi susu dan berat sapih anak. Makalah Lomba Penulisan Ilmiah Boedhi Rahardjani Award. Seminar Nasional Ikatan Ahli Ilmu Faal Indonesia, Bandungan, Semarang. 26-28 Oktober 1995
Sumaryadi, M. Y. dan W. Manalu. 1996. Pengaruh jumlah fetus terhadap konsentrasi progesteron dalam serum induk domba selama fase plasentasi periode kebuntingan. Prosiding Seminar Nasional Peternakan dan Veteriner. Pusat Penelitian dan Pengembangan Peternakan, Badan Penelitian dan Pengembangan Pertanian, Departemen Pertanian. Halaman 441-445.

Tucker, H. A. 1987. Quantitative estimates of mammary growth during various physiological state: A review. J. Dairy Sci. 70:1958-1966.

Turner, C. W. 1959. The experimental induction of growth of the cows udder and the initiation of milk secretion. Research Bulletin 697:1-36.

Wahab, I. M. and R. R. Anderson. 1989 Physiologic role of relaxin on mammary gland growth in rats. Proc. Soc. Exp. Biol. Med. $192: 285-289$

Webb J. M. and M. B. Levy. 1955. A Sensitive methode for the determination of deoxyribonucleic acid in tissue and microorganism. J. Biol. Chem. 213:107-113.

Wilde, C. J. and C. H. Knight. 1989 Metabolic adaptations in mammary gland during the declining phase of lactation. J. Dairy Sci. 72: 1679-1692

Winder, S J. and I. A. Forsyth 1986 Insulin-like growth factor I (IGF-I) is a potent mitogen for ovine mammary epithelial cells. J. Endocrin. 106 (suppl.) : 141

Wossner, F. J. 1961. The determination of hídroxyproline in tissue and protein sample containing small proportions of this amino acid. Arch. Biochem. Biophys 93:440-447.

Wright, L. C. and R. R. Anderson. 1982. Effect of relaxin on mammary growth in the hypophysectomized rat. In: Relaxin. Anderson, R. R. Ed. Plenum Press, New York. pp. 341-353. 